\title{
Water and dissolved gas geochemistry of the monomictic Paterno sinkhole (central Italy)
}

\author{
Franco TASSI,${ }^{1,2^{*}}$ Jacopo CABASSI, ${ }^{1}$ Dmitri ROUWET, ${ }^{3}$ Roberto PALOZZI,${ }^{4}$ Massimiliano MARCELLI,${ }^{5}$ \\ Marco QUARTARARO, ${ }^{6}$ Francesco CAPECCHIACCI, ${ }^{1,2}$ Matteo NOCENTINI, ${ }^{1}$ Orlando VASELLI ${ }^{1,2}$
}

\begin{abstract}
${ }^{1}$ University of Firenze, Department of Earth Sciences, Via G. La Pira 4, 50121 Firenze, Italy; ${ }^{2} \mathrm{CNR}-$ Institute Geosciences and Earth Resources, Via G. La Pira 4, 50121 Firenze, Italy; ${ }^{3}$ INGV-Geochemical Section, Via Ugo La Malfa 153, 90146 Palermo, Italy; ${ }^{4}$ University of Tuscia, Department of Agricolture, Forests, Nature and Energy (DAFNE), Via San Camillo de Lellis, 01100 Viterbo, Italy; 'University of Roma "La Sapienza", Department of Animal and Human Biology, Viale dell'Università 32, 00185 Roma, Italy; ${ }^{6}$ University of Roma "Tor Vergata", Department of Biology, Via della Ricerca Scientifica, 00133 Roma, Italy.

*Corresponding author: franco.tassi@unifi.it
\end{abstract}

\begin{abstract}
This paper describes the chemical and isotope features of water and dissolved gases from lake Paterno (max. depth $54 \mathrm{~m}$ ), a sinkhole located in the NE sector of the S. Vittorino plain (Rieti, Central Italy), where evidences of past and present hydrothermal activity exists. In winter (February 2011) lake Paterno waters were almost completely mixed, whereas in summer time (July 2011) thermal and chemical stratifications established. During the stratification period, water and dissolved gas chemistry along the vertical water column were mainly controlled by biological processes, such as methanogenesis, sulfate-reduction, calcite precipitation, denitrification, and $\mathrm{NH}_{4}$ and $\mathrm{H}_{2}$ production. Reducing conditions at the interface between the bottom sediments and the anoxic waters are responsible for the relatively high concentrations of dissolved iron ( $\mathrm{Fe}$ ) and manganese $(\mathrm{Mn})$, likely present in their reduced oxidation state. Minerogenic and biogenic products were recognized at the lake bottom even during the winter sampling. At relatively shallow depth the distribution of $\mathrm{CH}_{4}$ and $\mathrm{CO}_{2}$ was controlled by methanotrophic bacteria and photosynthesis, respectively. The carbon isotope signature of $\mathrm{CO}_{2}$ indicates a significant contribution of deep-originated inorganic $\mathrm{CO}_{2}$ that is related to the hydrothermal system feeding the $\mathrm{CO}_{2}$-rich mineralized springs discharging in the surrounding areas of lake Paterno. The seasonal lake stratification likely controls the vertical and horizontal distribution of fish populations in the different periods of the year.
\end{abstract}

Key words: monomictic lake, sinkhole, lake Paterno, water lake chemistry, dissolved gas chemistry.

Received: January 2012. Accepted: April 2012.

\section{INTRODUCTION}

The term sinkhole was introduced by Fairbridge (1968) to indicate a sub-circular depression formed by the collapse of small subterranean karst cavities. Genetic classifications for sinkholes related to karst processes have recently been proposed (e.g. Williams, 2003; Neuendorf et al., 2005; Waltham et al., 2005), allowing to distinguish sinkholes produced by i) dissolutional lowering of the ground surface and ii) subsurface karstification. Sinkholes were classified on the basis of i) genetic processes (i.e. collapse, suffusion or sagging) and ii) type of collapsing material (bedrock, cover or caprock) (Gutierrez et al., 2008). In the Italian literature, sinkhole often stands for collapse phenomena not directly linked to karst dissolution, such as those caused by both anthropogenic activities and deep piping processes due to the presence of carbonate bedrock buried under a thick sedimentary cover (Ciotoli et al., 2001; Salvati and Sasowsky, 2002; Nisio, 2003; Nisio et al., 2005, 2007; Caramanna et al., 2008). A significant percentage of sinkholes in Italy $(\approx 38 \%)$ hosts lakes or ponds (Nisio et al., 2007). In the Latium re- gion (central Italy), 34 zones prone to sinkhole formation through deep piping processes are recognized and include 163 active, filled and buried sinkholes (Caramanna et al., 2008). Among these zones, the S. Vittorino Plain (eastern Latium) is characterized by the presence of at least 35 sinkholes with diameters from a few to $200 \mathrm{~m}$. The origin of sinkholes in this area is mainly related to deep piping processes caused by $\mathrm{CO}_{2-}$ and $\mathrm{H}_{2} \mathrm{~S}$-rich fluid upwelling along fracture-fault systems (Caramanna et al., 2008). The presence of hydrothermal fluids at depth of a lake resembles the situation at Nyos-type maar lakes, prone to stratification and gas accumulation at depth, which can eventually be liberated by lake overturn (Kling et al., 1987; Kusakabe et al., 2000).

Lake Paterno is located in the NE sector of the San Vittorino Plain (Fig. 1), has a sub-circular shape and a maximum diameter of about $190 \mathrm{~m}$. This lake, indicated by Marco Terenzio Varrone (116- 27 B.C.) as the Umbilicus Italiae, is the biggest active sinkhole in the San Vittorino Plain. It is known since pre-Roman Age, because of the presence of a small floating island, which was possibly 
consisting of carbonate incrustations lying on tree branches and trunks, where religious ceremonies were celebrated (Persichetti, 1893, 1910; Aliotta, 1982; Marinelli, 1995).

This paper examines the distribution of chemical (major, minor and trace compounds) and isotope compositions of water and dissolved gases along the vertical water column of the lake sampled in winter (February) and summer (July) 2011. The main aim of this study is to investigate the processes, such as i) water-rock interactions, ii) biological activity and iii) external fluid inputs, likely controlling the seasonal evolution of the water and dissolved gas chemistry.

\section{Geological and hydrological settings of the study area}

San Vittorino Plain, located in the Velino watershed, $20 \mathrm{~km}$ east of the town of Rieti, is a triangular-shaped intramontane depression, with a total surface of $7 \mathrm{~km}^{2}$, bordered by direct and transtensive faults (Ciotoli et al., 1998, 2001; Centamore and Nisio, 2003; Centamore et al., 2004). The valley is mainly filled by Pleistocene and Upper-Holocene fluvial deposits with a maximum thickness of $170 \mathrm{~m}$ and placed over a faulted calcareous se- quence (Nisio, 2003). The main tectonic structures are represented by the Anzio-Ancona and the Olevano-Micciani lines and by the Fiamignano-Micciani and the Cerquara-Piedimozza faults (Centamore et al., 2009). In the valley, several thermal and mineral springs (e.g. Cotilia sulfur spring), areas of anomalous soil degassing, as well as travertine deposits testifying past and present hydrothermal activity, are present (Brancaccio et al., 1988; Faccenna et al., 1993; Ciotoli et al., 2001; Minissale et al., 2002; Nisio, 2003). The spatial distribution of the San Vittorino sinkholes, mainly located in the northern sector of the plain, is strongly controlled by the NNW-trending and SW-dipping Fiamignano-Micciani fault (Faccenna et al., 1993; Capelli et al., 2000; Bersani and Castellano, 2002; Nisio, 2003, 2008; Annunziatellis et al., 2004; Nisio et al. 2007) (Fig. 1). West of the Fiamignano-Micciani fault, a few collapse events are recorded (Faccenna et al., 1993; Ciotoli et al., 1998; Centamore et al., 2002, 2004). The spatial distribution of the sinkholes suggests that their formation is mainly related to the collapsed sector of the Mt. Paterno block, whose structural setting favors the development of confined aquifers (Centamore et al., 2009). Several sinking events

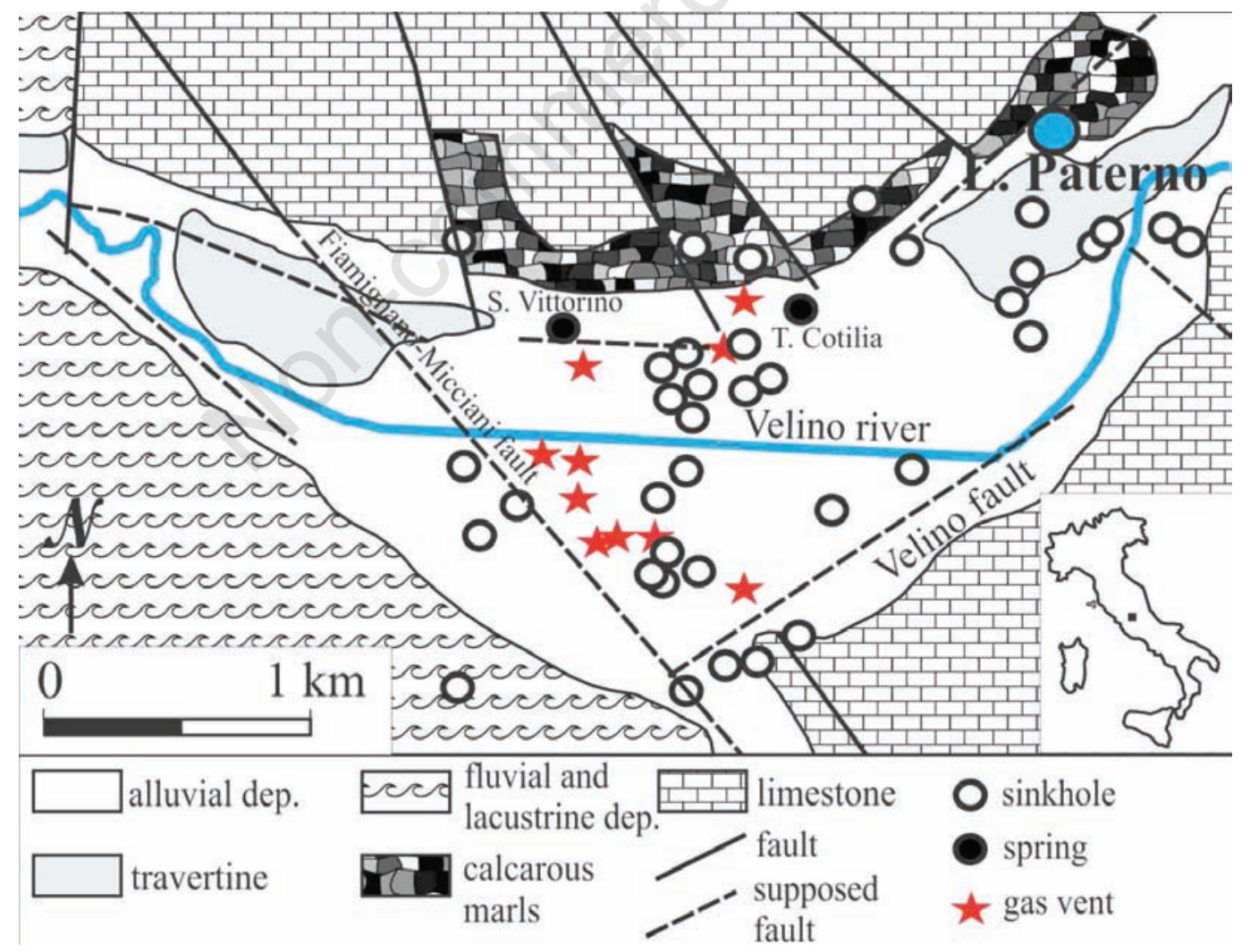

Fig. 1. Geological schematic map of San Vittorino plain and location of lake Paterno and San Vittorino (SV) and Terme Cotilia (TC) mineral springs. 
have occurred in this area during historical times, the first one being recorded in 1703 following an earthquake that damaged the San Vittorino church built between 1604 and 1614 (Annunziatellis et al., 2004). Between 1770 and 1850, five sinkholes formed (Riccardi, 1951; Capelli et al., 2000; Bersani and Castellano, 2002). In 1886, three depressions with diameters from 5 to $60 \mathrm{~m}$ formed in the Sciamagutta area (Catenacci, 1992), whilst in 1915, after the Avezzano earthquake, the Pozzo Gustavo, well-like cavity opened (Michetti et al., 1994). Small sinkholes also formed during the last two decades, the latest being opened in September 2003 (Annunziatellis et al., 2004). In the past century, several sinkholes also reactivated (Riccardi, 1951), including that of lake Paterno whose maximum depth in 1915, 15 days after the Marsica earthquake, passed from 37.7 to $45.2 \mathrm{~m}$ (Crema, 1924); a further deepening occurred in the $1950 \mathrm{~s}$, when the lake achieved the present depth of $54 \mathrm{~m}$.

\section{METHODS}

\section{Water and dissolved gas sampling}

Water and dissolved gas sampling was carried out during two field campaigns in February and July 2011 along vertical profiles from the lake surface to the bottom at regular intervals of $5 \mathrm{~m}$, at a site corresponding to the deepest point of the lake. Water and dissolved gas sampling was carried out using a Rilsan ${ }^{\circledR}$ tube $(6 \mathrm{~mm}$ in diameter). Once one end of the Rilsan ${ }^{\circledR}$ tube was lowered to the chosen depth, water was pumped up to the surface by means of a $150 \mathrm{~mL}$ glass syringe connected to the other end of the tube via a three way valve, and transferred into the storage containers (Tassi et al., 2004, 2009). Following this procedure, the sampling was carried out from the lake surface to the bottom. Water and dissolved gases were collected after the displacement of a water volume at least twice the inner volume of the tube $\left(0.0283 \mathrm{dm}^{3} \mathrm{~m}^{-1}\right)$ (Tassi et al., 2004).

One filtered $(0.45 \mu \mathrm{m})$ and two filtered-acidified (with ultrapure $\mathrm{HCl}$ and ultrapure $\mathrm{HNO}_{3}$, respectively) water samples were collected in polyethylene bottles for the analysis of anions, cations and trace species. A fourth water aliquot was collected in glass bottles and few tens of milligrams of $\mathrm{HgCl}_{2}$ were added for the determination of oxygen and hydrogen (in water) and carbon (dissolved inorganic carbon, DIC) isotopes. For the two mineral springs discharging close to lake Paterno (SV, San Vittorino - TC, Terme di Cotilia), the filtered, the filtered-( $\mathrm{HCl})$ acidified and the glass bottles aliquots were collected.

Dissolved gases were collected into one-way, pre-evacuated $250 \mathrm{~mL}$ glass vials equipped with a Teflon stopcock (Chiodini, 1996; Caliro et al., 2008; Tassi et al., 2008). The gas vial was connected to the Rilsan ${ }^{\circledR}$ tube through a threeway valve, avoiding possible air contamination by filling the connection with lake water. Then, the stopcock was opened to partly fill ( $75 \%$ of the total volume) the gas vial with water. Part of the gas stored in the sampling flask headspace was transferred into pre-evacuated $10 \mathrm{~mL}$ glass flasks equipped with a Teflon stopcock. This aliquot was used for the analyses of the ${ }^{13} \mathrm{C} /{ }^{12} \mathrm{C}$ ratios of dissolved $\mathrm{CO}_{2}$ $\left(\delta^{13} \mathrm{C}-\mathrm{CO}_{2 \text { STRIP }}\right)$ and the ${ }^{13} \mathrm{C} /{ }^{12} \mathrm{C}$ and ${ }^{2} \mathrm{H} /{ }^{1} \mathrm{H}$ ratios of $\mathrm{CH}_{4}$ $\left(\delta^{13} \mathrm{C}-\mathrm{CH}_{4}\right.$ and $\delta \mathrm{D}-\mathrm{CH}_{4}$, respectively).

\section{Field measurements and analytical methods}

Temperature $\left(\mathrm{T}\right.$, in $\left.{ }^{\circ} \mathrm{C}\right), \mathrm{pH}$, dissolved oxygen $\left(\mathrm{O}_{2}\right.$ in $\mathrm{mg} \mathrm{L}^{-1}$ ), and electrical conductivity ( $\mathrm{EC} \mathrm{in} \mathrm{mS} \mathrm{cm}^{-1}$ ) were measured along the vertical profile were measured using a Hydrolab multiparameter probe (Idroprobe) equipped with a data logger for data storage. The nominal precisions are as follows: $\operatorname{depth}= \pm 0.05 \mathrm{~m} ; \mathrm{T}= \pm 0.03^{\circ} \mathrm{C} ; \mathrm{O}_{2}= \pm 0.05 \mathrm{mg}$ $\mathrm{L}^{-1} \mathrm{EC}= \pm 0.01 \mathrm{mS} \mathrm{cm}{ }^{-1}, \mathrm{pH}= \pm 0.02$. Alkalinity was measured by acidimetric titration $(\mathrm{HCl} 0.01 \mathrm{~N})$ in the field. The analytical error for alkalinity analysis was $\leq 2 \%$.

The main anions $\left(\mathrm{Cl}^{-}, \mathrm{SO}_{4}{ }^{2-}, \mathrm{NO}_{3}{ }^{-}, \mathrm{Br}^{-}\right.$and $\left.\mathrm{F}^{-}\right)$and cations $\left(\mathrm{Na}^{+}, \mathrm{K}^{+}, \mathrm{Ca}^{2+}, \mathrm{Mg}^{2+}, \mathrm{NH}_{4}^{+}\right.$and $\left.\mathrm{Li}^{+}\right)$of water samples were analyzed by ion-chromatography (IC) (Metrohm 761 and Metrohm 861, respectively). Trace elements (A1, As, B, Ba, Cd, Cs, Cu, Fe, Mn, Mo, Ni, P, Pb, Rb, Sb, Sc, $\mathrm{Si}, \mathrm{Sr}, \mathrm{U}, \mathrm{V}$, and $\mathrm{Zn}$ ) were analyzed at the Acme Laboratories of Vancouver (Canada) by Inductively Coupled Plasma Mass Spectrometry (ICP-MS) with a Perkin-Elmer ELAN 6600 spectrometer. The analytical errors for IC and ICP-MS were $\leq 5$ and $\leq 10 \%$, respectively.

The ${ }^{18} \mathrm{O} /{ }^{16} \mathrm{O}$ and ${ }^{2} \mathrm{H} /{ }^{1} \mathrm{H}$ ratios (expressed as $\delta^{18} \mathrm{O}-\mathrm{H}_{2} \mathrm{O}$ and $\delta \mathrm{D}-\mathrm{H}_{2} \mathrm{O} \% \mathrm{~V}$-SMOW, respectively) were determined with a Finningan Delta Plus XL mass spectrometer according to standard protocols. Water samples were equilibrated with $\mathrm{CO}_{2}$ for the analysis of the $\delta^{18} \mathrm{O}-\mathrm{H}_{2} \mathrm{O}$ values (Epstein and Mayeda, 1953). The $\delta \mathrm{D}-\mathrm{H}_{2} \mathrm{O}$ values were measured on $\mathrm{H}_{2}$ obtained after the reaction of $10 \mu \mathrm{L}$ of water with metallic zinc at $500^{\circ} \mathrm{C}$, following the analytical procedure proposed by Coleman et al. (1982). San Vincenzo marble (SV1) and AR1 water, calibrated vs VSMOW and SLAP reference standards, were used as external standards. The experimental errors were \pm 0.1 and $\pm 1 \%$ for the $\delta^{18} \mathrm{O}-\mathrm{H}_{2} \mathrm{O}$ and $\delta \mathrm{D}-\mathrm{H}_{2} \mathrm{O}$ values, respectively.

The ${ }^{13} \mathrm{C} /{ }^{12} \mathrm{C}$ ratios of DIC (expressed as $\delta^{13} \mathrm{C}_{\text {DIC }} \%$ V$\mathrm{PDB}$ ) were determined on $\mathrm{CO}_{2}$ produced by reaction of 3 $\mathrm{mL}$ of water with $2 \mathrm{~mL}$ of anhydrous phosphoric acid in pre-evacuated tubes (Salata et al., 2000) using a Finningan Delta Plus XL mass spectrometer. The recovered $\mathrm{CO}_{2}$ was analyzed after a two-step extraction and purification procedures of the gas mixtures by using liquid $\mathrm{N}_{2}$ and a solid-liquid mixture of liquid $\mathrm{N}_{2}$ and trichloroethylene (Evans et al., 1998; Vaselli et al., 2006). The analytical error for $\delta^{13} C_{\text {DIC }}$ was \pm 0.05 .

Dissolved gas composition was calculated from the composition of the gas phase stored in the headspace of 
the sampling glass flasks on the basis of i) gas pressure, ii) headspace volume and iii) the solubility coefficients of each gas compound (Whitfield, 1978). The inorganic compounds in the flask headspace $\left(\mathrm{CO}_{2}, \mathrm{~N}_{2}, \mathrm{O}_{2}, \mathrm{Ar}\right.$, Ne and $\mathrm{H}_{2}$ ) were analyzed with a gas-chromatograph (Shimadzu 15A) equipped with a Thermal Conductivity Detector (TCD), while $\mathrm{CH}_{4}$ was analyzed with a Shimadzu 14A gas-chromatograph equipped with a Flame Ionization Detector (FID) (Tassi et al., 2004). The analytical error for dissolved gas analysis was $\leq 5 \%$. The $\delta^{13} \mathrm{C}_{-} \mathrm{CO}_{2 \text { STRIP }}$ analyses (expressed as \%o V-PDB) were carried out with a Finningan Delta $S$ mass spectrometer after purification of the gas mixture by standard procedures (Evans et al., 1998; Vaselli et al., 2006). Internal (Carrara and San Vincenzo marbles) and international (NBS18 and NBS19) standards were used to estimate external precision. The analytical error and the reproducibility were $\pm 0.05 \%$ and $\pm 0.1 \%$, respectively.

The analysis of $\delta^{13} \mathrm{C}_{-} \mathrm{CH}_{4}$ and $\delta \mathrm{D}-\mathrm{CH}_{4}$ (expressed as $\%$ V-PDB and \%o V-SMOW, respectively) were carried out by mass spectrometry (Varian MAT 250) according to the procedure described by Schoell (1980). The analytical error was $\pm 0.15 \%$.

\section{RESULTS}

\section{Lake morphology}

Lake Paterno is located at an altitude of $430 \mathrm{~m}$ asl and has an ellipsoidal shape $(190 \mathrm{~m} \times 150 \mathrm{~m})$, a surface of about $22,300 \mathrm{~m}^{2}$, a volume of $1.05 \times 10^{6} \mathrm{~m}^{3}$ and a maximum depth of $54 \mathrm{~m}$. An artificial channel discharges the lake water into the Velino river at a flow rate of $16 \mathrm{~L} \mathrm{sec}^{-1}$. This unequivocally indicates that the lake is fed by sub-lacustrine springs, although no direct evidences are reported. Lake bathymetry (Fig. 2) was obtained in February 2011 when the lake depth was measured at 50 different sites, evenly distributed, using a Humminbird Legend 1005 portable Eco-sonar. The ratio between the average depth and the maximum depth of lake Paterno is 0.87 , i.e. the lake shape approximates a steep-sided frustum model corresponding to steep sides and flat bottom (Lehman, 1975), typical of lakes of recent formation and affected by elevated sedimentation rates. The relatively high value of this parameter, known as depth-ratio (Carpenter, 1983), indicates that the morphology of lake Paterno tends to favour water stratification (Hutchinson, 1957).

\section{Temperature, EC, $\mathrm{pH}$ and dissolved $\mathrm{O}_{2}$ vertical profiles}

Temperature (in ${ }^{\circ} \mathrm{C}$ ), EC, $\mathrm{pH}$, and dissolved $\mathrm{O}_{2}$ concentrations (in $\mathrm{mg} \mathrm{L}^{-1}$ ) along the vertical profiles of lake Paterno are shown in Fig. 3 a,d. In February 2011, water temperature $\left(\sim 6.5^{\circ} \mathrm{C}\right)$ did not display any significant variation with depth. In July 2011 the lake surface was relatively warm (up to $23.2^{\circ} \mathrm{C}$ ) and two thermoclines occurred at depths of 4-6 $\mathrm{m}$ and, less pronounced, $\sim 35 \mathrm{~m}$, respectively. Water temperature at the lake bottom $\left(7.4^{\circ} \mathrm{C}\right)$ slightly exceeded that measured in February $\left(6.5^{\circ} \mathrm{C}\right)$ (Fig. 3a). The vertical pattern of EC in February (Fig. 3b) was constant $\left(\sim 0.64 \mathrm{mS} \mathrm{cm}^{-1}\right)$ up to the depth of $-35 \mathrm{~m}$, then it increased at -35 and $-52.5 \mathrm{~m}$ depth, up to 0.66 and 0.73 $\mathrm{mS} \mathrm{cm}{ }^{-1}$, respectively. In July, EC of the surface lake water was relatively low $\left(0.53 \mathrm{mS} \mathrm{cm}^{-1}\right)$, and rapidly increased with depth reaching $\sim 0.76 \mathrm{mS} \mathrm{cm}^{-1}$ at the depth of $-13 \mathrm{~m}$; a second significant $\mathrm{EC}$ increasing trend started at the depth of $\sim 45 \mathrm{~m}$ and the maximum EC value was $0.89 \mathrm{mS}$ $\mathrm{cm}^{-1}$ at the lake bottom (Fig. 3b). The $\mathrm{pH}$ vertical profiles had a $S$ shape for both February and July (Fig. 3c). They indeed showed maximum $\mathrm{pH}$ at the lake surface ( 7.75 and 8.13 in February and July, respectively), a rapid decrease (down to 7.2 and 7.3 in February and July, respectively) between 0 and $-10 \mathrm{~m}$ depth, and a flat pattern approaching the lake bottom where they showed a significant further decrease (down to 7.18 and 6.97 in February and July, respectively). Dissolved $\mathrm{O}_{2}$ in February was relatively constant $\left(\sim 6 \mathrm{mg} \mathrm{L}^{-1}\right)$ down to the depth of $51 \mathrm{~m}$, where it suddenly decreased reaching $2.1 \mathrm{mg} / \mathrm{L}$ at the lake bottom (Fig. 3d). On the contrary, in July the dissolved $\mathrm{O}_{2}$ concentrations were relatively high in the shallow waters (up to $12.7 \mathrm{mg} \mathrm{L}^{-1}$ at the depth of $8.7 \mathrm{~m}$ ) and then showed a rapid decrease at increasing depths $\left(<0.1 \mathrm{mg} \mathrm{L}^{-1}\right.$ at depths $>12.5 \mathrm{~m}$ ) (Fig. 3d). The occurrence of anoxic water below the shallower thermocline may explain the macro-invertebrate population dynamics observed during underwater visual census carried out in different seasons since 2009 (Palozzi et al., 2010). In summer, fishes are only found in the epilimnion, i.e. the only portion of the lake where free-

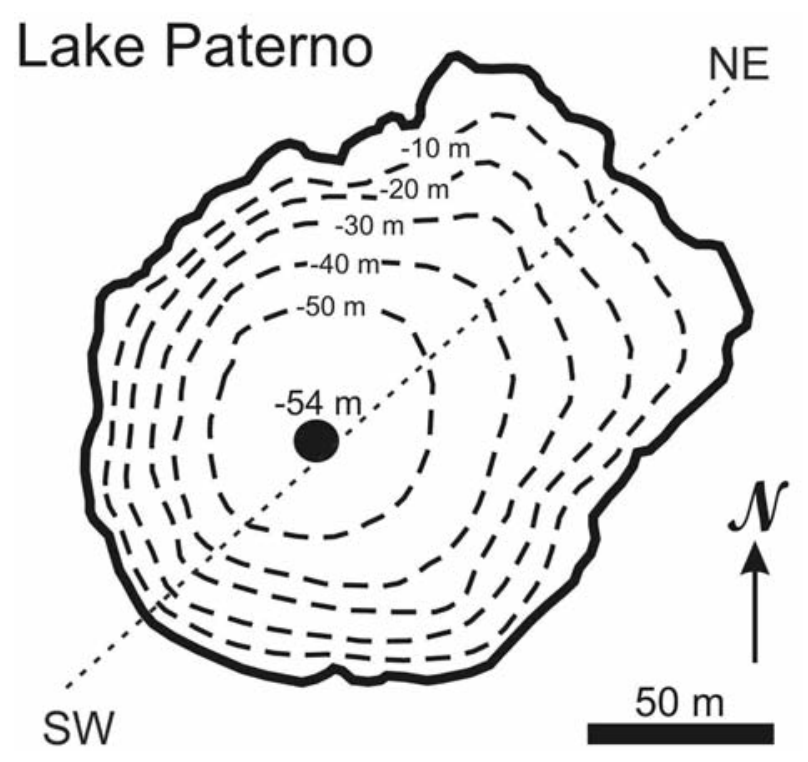

Fig. 2. Bathymetric map of lake Paterno. 
$\mathrm{O}_{2}$ is available; in winter, fishes populate the deep waters, since water vertical mixing transports oxygenated water down to the lake bottom.

\section{Chemical and isotope $\left(\delta^{18} \mathrm{O}-\mathrm{H}_{2} \mathrm{O}, \delta \mathrm{D}-\mathrm{H}_{2} \mathrm{O}\right.$ and $\left.\delta^{13} \mathrm{C}_{\text {DIC }}\right)$ compositions of waters}

Chemical composition (in mg/L) and $\delta^{18} \mathrm{O}-\mathrm{H}_{2} \mathrm{O}, \delta \mathrm{D}-$ $\mathrm{H}_{2} \mathrm{O}$ and $\delta^{13} \mathrm{C}_{\text {DIC }}$ ratios of lake Paterno water, as well as those of San Vittorino (SV) and Terme Cotilia (TC) mineral spring waters, are listed in Tab. 1. Trace element concentrations are reported in Tab. 2.

Lake Paterno had a $\mathrm{Ca}^{2+}-\mathrm{HCO}_{3}{ }^{-}$composition and TDS values $<850 \mathrm{mg} \mathrm{L}^{-1}$, typical of worldwide superficial waters and shallow aquifers, and similar to that recorded for the SV and TC springs. Nevertheless, the latter are characterized by significantly higher TDS concentrations (2730 and $3100 \mathrm{mg} \mathrm{L}^{-1}$, respectively) with respect to those of lake
Paterno. These geochemical features are consistent with the analytical data reported by Annunziatellis et al. (2004). The concentrations of $\mathrm{Cl}^{-}$(from 5.2 to $8.2 \mathrm{mg} \mathrm{L}^{-1}$ ), $\mathrm{Mg}^{2+}$ (from 22 to $27 \mathrm{mg} \mathrm{L}^{-1}$ ), $\mathrm{Na}^{+}$(from 4.7 to $5.9 \mathrm{mg} \mathrm{L}^{-1}$ ) and $\mathrm{K}^{+}$(from 1.6 to $3.2 \mathrm{mg} \mathrm{L}^{-1}$ ) of the lake waters did not show significant variations with depth neither with time. Sulfate concentrations were relatively constant from the surface to the depth of $50 \mathrm{~m}$ (from 32 to 34 and from 35 to $39 \mathrm{mg}$ $\mathrm{L}^{-1}$ in February and July, respectively), whereas they significantly decreased at the lake bottom, clustering around $25 \mathrm{mg} \mathrm{L}^{-1}$ for both surveys. An opposite behavior was shown by $\mathrm{Ca}^{2+}$ concentrations, which ranged from 137 to $143 \mathrm{mg} \mathrm{L}^{-1}$ from the surface to $-50 \mathrm{~m}$ depth (with the exception of the shallow water samples collected in July: $\leq 120 \mathrm{mg} \mathrm{L}^{-1}$ ), whereas at the lake bottom $\mathrm{Ca}^{2+}$ contents increased up to 156 (February) and 148 (July) $\mathrm{mg} \mathrm{L}^{-1}$. In February, the $\mathrm{HCO}_{3}$ - vertical profile had two peaks (up to 519 and $525 \mathrm{mg} \mathrm{L}^{-1}$ ) at the depth of 35 and $54 \mathrm{~m}$, respec-

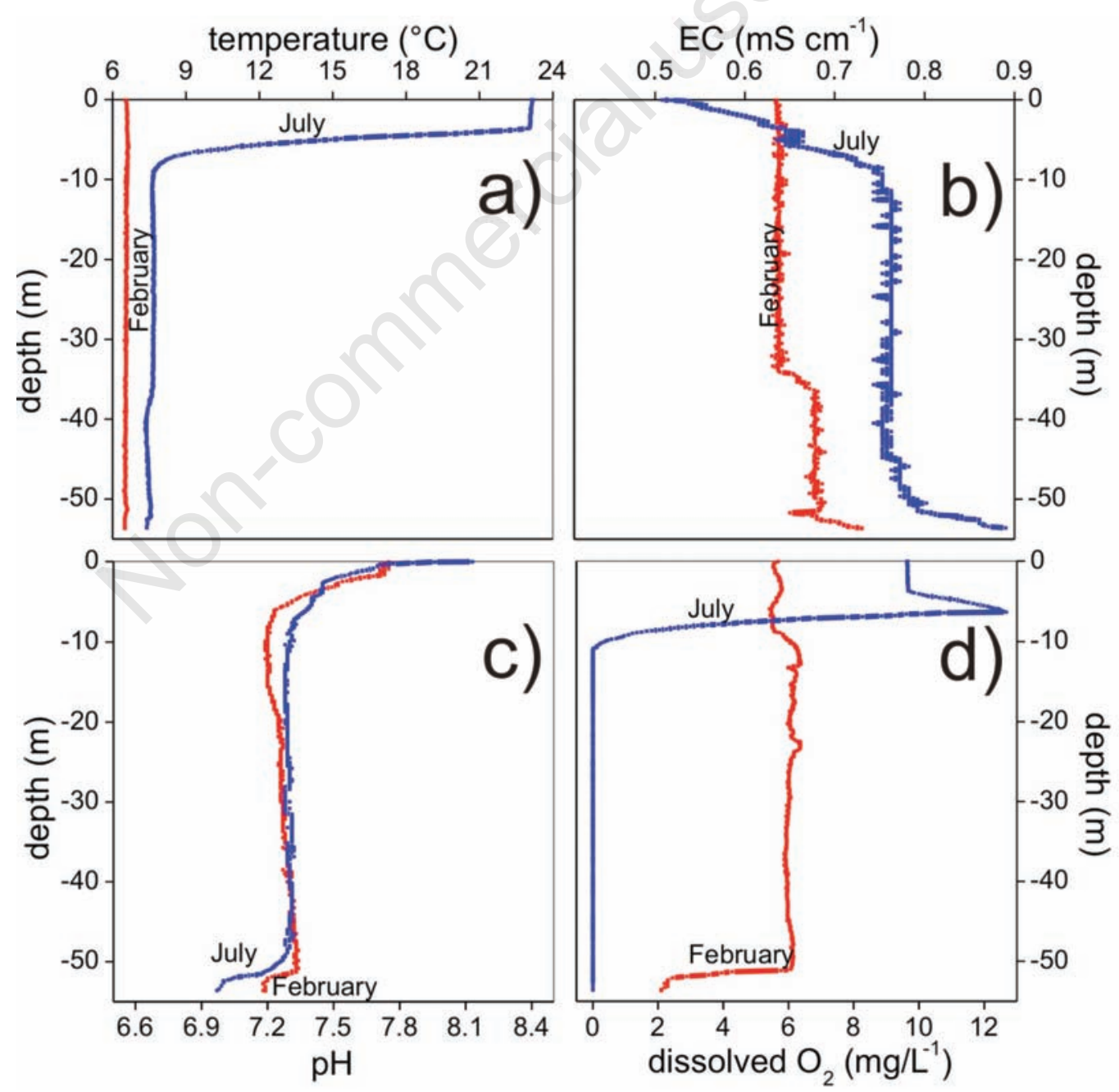

Fig. 3. Vertical profiles of a) water temperature; b) electrical conductivity (EC); c) pH; and d) dissolved $\mathrm{O}_{2}$ concentrations of lake Paterno measured from the surface to the bottom in February and June 2011. 


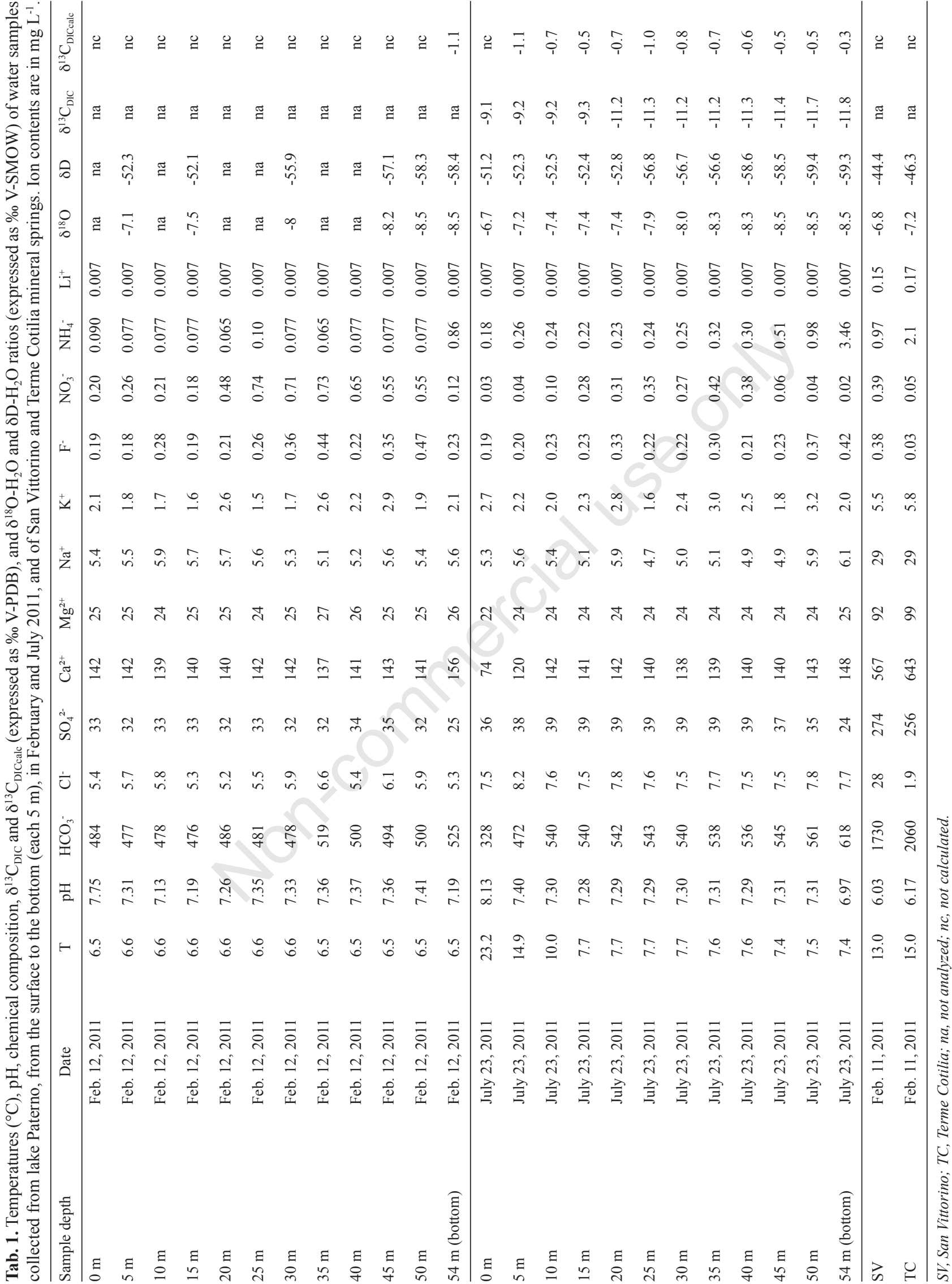


tively; in July, the $\mathrm{HCO}_{3}^{-}$concentrations strongly increased from the lake surface $\left(328 \mathrm{mg} \mathrm{L}^{-1}\right)$ to $-10 \mathrm{~m}(540$ $\mathrm{mg} \mathrm{L}^{-1}$ ) and from -45 to $-54 \mathrm{~m}$ depth (up to $618 \mathrm{mg} \mathrm{L}^{-1}$ ) (Fig. 4a). The two vertical patterns of the $\mathrm{NO}_{3}{ }^{-}$concentrations (from 0.12 to 0.74 and from 0.03 to $0.42 \mathrm{mg} \mathrm{L}^{-1}$ in February and July, respectively) consistently showed a significant increase of this compound at depth between 15 and $40 \mathrm{~m}$, followed by a sharp decrease as approaching the lake bottom (Fig. 4b). Conversely, both trends of $\mathrm{NH}_{4}^{+}$ had significant increases close to the lake bottom, where $\mathrm{NH}_{4}^{+}$concentrations were 0.86 and $3.46 \mathrm{mg} \mathrm{L}^{-1}$ in February and July, respectively (Fig. 4c). The water samples collected at the lake bottom during the two sampling campaigns showed anomalously high concentrations of several trace elements with respect to those of the shallower waters, e.g. Ba (up to $100 \mu \mathrm{g} \mathrm{L}^{-1}$ ), Fe (up to $290 \mu \mathrm{g} \mathrm{L}^{-1}$ ), Mn (up to $1170 \mu \mathrm{g} \mathrm{L}^{-1}$ ), P (up to $560 \mu \mathrm{g} \mathrm{L}^{-1}$ ), and Si (up to $\left.4950 \mu \mathrm{g} \mathrm{L}^{-1}\right)$.

The $\delta^{18} \mathrm{O}-\mathrm{H}_{2} \mathrm{O}$ and $\delta \mathrm{D}-\mathrm{H}_{2} \mathrm{O}$ values of the two samplings were consistent and ranged from -8.5 to -6.7 and from -59.3 to $-51.2 \%$ V-SMOW, respectively. The $\delta^{13} \mathrm{C}_{\text {DIC }}$ ratios, which were analyzed in summer, ranged from -11.8 to $-9.1 \%$ V-PDB, and regularly decreased from the lake surface to the bottom.

\section{Chemical and isotope $\left(\delta^{13} \mathrm{C}-\mathrm{CO}_{2}, \delta^{13} \mathrm{C}-\mathrm{CH}_{4}\right.$ and $\left.\delta \mathrm{D}-\mathrm{CH}_{4}\right)$ compositions of dissolved gases}

The chemical composition of the dissolved gases (in $\left.\mu \mathrm{mol} \mathrm{L}{ }^{-1}\right)$ is shown in Tab. 3, while the $\delta^{13} \mathrm{C}-\mathrm{CO}_{2}, \delta^{13} \mathrm{C}$ $\mathrm{CH}_{4}$ and $\delta \mathrm{D}-\mathrm{CH}_{4}$ ratios are reported in Tab. 4 .

In February, the concentrations of most of the main dissolved gases, i.e. $\mathrm{N}_{2}$, Ar, and $\mathrm{Ne}$ (up to 781, 16 and 0.08 $\mu \mathrm{mol} \mathrm{L}{ }^{-1}$, respectively) did not show significant variations along the vertical profile, $\mathrm{O}_{2}$ ranged between 148 and 164 $\mu \mathrm{mol} \mathrm{L} \mathrm{L}^{-1}$ from the lake surface to the depth of $45 \mathrm{~m}$ and then decreased to $\mu \mathrm{mol} \mathrm{L^{-1 }}$ at $54 \mathrm{~m}$. The concentrations of $\mathrm{H}_{2}$ were $<1 \mu \mathrm{mol} \mathrm{L} \mathrm{L}^{-1}$ and $\mathrm{CO}_{2}$ and $\mathrm{CH}_{4}$ (up to 155 and 15 umol L $\mathrm{L}^{-1}$, respectively) were only detected at depth $>45 \mathrm{~m}$. In July, $\mathrm{N}_{2}$, Ar and $\mathrm{Ne}$ (up to 679, 17 and $0.01 \mu \mathrm{mol} \mathrm{L} \mathrm{L}^{-1}$, respectively) showed patterns similar to those of the February campaign. On the contrary, $\mathrm{O}_{2}$ rapidly decreased with depth and was $<1 \mu \mathrm{mol} \mathrm{L}-1$ (detection limit) below $15 \mathrm{~m}$ depth, in agreement with the data measured using the Idrolab multiprobe (Fig. 3d). Methane, $\mathrm{CO}_{2}$ and $\mathrm{H}_{2}$ strongly increased with depth up to 426, 493 and 334 $\mu \mathrm{mol} \mathrm{L}{ }^{-1}$, respectively, at the lake bottom.

To calculate the $\delta^{13} \mathrm{C}$ ratios of dissolved $\mathrm{CO}_{2}\left(\delta^{13} \mathrm{C}\right.$ $\mathrm{CO}_{2}$ ) from the measured $\delta^{13} \mathrm{C}-\mathrm{CO}_{2 \mathrm{STRIP}}$ ratios, the ${ }^{13} \mathrm{C}$ equilibrium fractionation between dissolved and gaseous $\mathrm{CO}_{2}$ due to liquid-to-gas transfer of $\mathrm{CO}_{2}$ during sampling was quantified by using the $\varepsilon_{1}$ factor suggested by Zhang et al. (1995) on the basis of empirical measurements, as follows:

$\varepsilon_{1}=\delta^{13} \mathrm{C}-\mathrm{CO}_{2}-\delta^{13} \mathrm{C}-\mathrm{CO}_{2 \mathrm{STRIP}}=0.0049 \times \mathrm{T}\left({ }^{\circ} \mathrm{C}\right)-1.31$ (eq. 1$)$ 


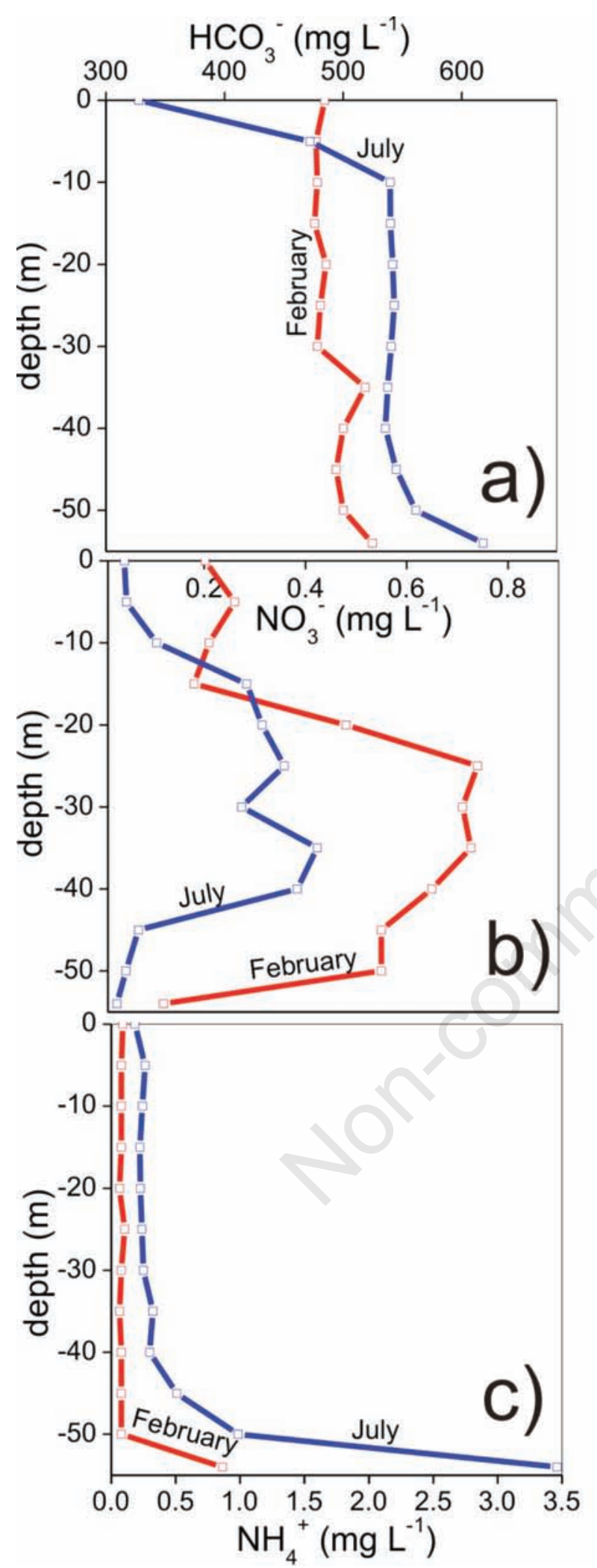

Fig. 4. Vertical profile of a) $\mathrm{HCO}_{3}^{-}$; b) $\mathrm{NO}_{3}^{-}$; and c) $\mathrm{NH}_{4}^{+}$concentrations of lake Paterno water in February and June 2011. Water samples were collected each $5 \mathrm{~m}$ from the surface to the bottom.
At $20^{\circ} \mathrm{C}$ (laboratory temperature) $\varepsilon_{1}$ is equal to -1.21 . The calculated $\delta^{13} \mathrm{C}-\mathrm{CO}_{2}$ value of the sample collected in February from the maximum depth was $-10.92 \%$ V-PDB, whereas those of samples collected in July slightly decreased from -10.10 to $-10.52 \%$ V-PDB passing from the -5 to $-25 \mathrm{~m}$ depth, whilst at depths $>25 \mathrm{~m}$ they regularly increased up to the lake bottom (-9.82\% V-PDB).

The $\delta^{13} \mathrm{C}_{-}-\mathrm{CH}_{4}$ and $\delta \mathrm{D}-\mathrm{CH}_{4}$ values of the sample collected at the maximum depth in February were $-60.9 \%$ VPDB and $-259 \%$ V-SMOW, respectively. In July, the $\delta^{13} \mathrm{C}_{-} \mathrm{CH}_{4}$ values significantly decreased with depth, from 56.1 (at $-20 \mathrm{~m}$ depth) to $-66.7 \%$ V-PDB (at $-54 \mathrm{~m}$ depth), whereas the $\delta \mathrm{D}-\mathrm{CH}_{4}$ ratios ranged between -258 and $-266 \%$ o $\mathrm{V}-\mathrm{SMOW}$ with no specific trends along the vertical profile.

\section{DISCUSSION}

\section{Origin of water and dissolved gases}

The $\delta^{18} \mathrm{O}-\mathrm{H}_{2} \mathrm{O}$ and $\delta \mathrm{D}-\mathrm{H}_{2} \mathrm{O}$ ratios of water collected from the lake bottom (Fig. 5) plot in correspondence to the local meteoric water line (LMWL) inferred by Giggenbach (1988) for precipitations in the Alban Hills, a volcanic system located about $70 \mathrm{~km} \mathrm{SW}$ of the study area. This indicates that the sub-lacustrine springs feeding lake Paterno have a meteoric origin. The isotopic compositions at different depths define a linear trend having a slope of about 5 with respect to the LMWL. Such slope is typically produced by evaporation in lakes at ambient temperature (Matsubaya and Sakai, 1978; Rowe, 1994). Therefore, the progressive increases of the $\delta^{18} \mathrm{O}-\mathrm{H}_{2} \mathrm{O}$ and $\delta \mathrm{D}-\mathrm{H}_{2} \mathrm{O}$ ratios at decreasing depth (Fig. 5) were likely due to downward circulation of water from the lake surface, where isotope fractionation caused by evaporation occurs. The water isotopic compositions of the SV and TC springs suggest that the thermal aquifer sourcing the mineral springs of the area through the main fault systems (Fiamignano-Micciani and the Velino faults) has a meteoric recharge. The high solute contents and relatively low $\mathrm{pH}$ ( 6) characterizing this deep aquifer (Tab. 1) are caused by addition of deep-originated gases, such as $\mathrm{CO}_{2}$ and $\mathrm{H}_{2} \mathrm{~S}$ (Annunziatellis et al., 2004). This hypothesis is corroborated by the hydrogeochemical conceptual model proposed by Petitta et al. (2011) suggesting that, on the basis of hydrochemical and isotopic data, the chemistry of the mineralized springs of the area is controlled by mixing between shallow $\mathrm{Ca}^{2+}-\mathrm{HCO}_{3}{ }^{-}$groundwater from carbonate aquifers and a highly saline thermal $\mathrm{Ca}^{2+}-\mathrm{HCO}_{3}-\mathrm{SO}_{4}{ }^{2-}$ endmember. The relatively low salinity of the lake (Tab. 1) suggests that water contribution from the deep thermal system, if present, is negligible. Nevertheless, non-atmospheric gases $\left(\mathrm{CO}_{2}, \mathrm{CH}_{4}\right.$ and $\left.\mathrm{H}_{2}\right)$ were detected at significant concentrations in the deep lake waters (Tab. 3). The strongly negative isotope signature of $\mathrm{CH}_{4}$ (Tab. 4) supports the idea that this gas is produced by methanogenic 
processes related to anaerobic activity of archeabacteria (Schoell, 1980; 1988; Barker and Fritz, 1981), occurring in the lake as well as within the lake bottom sediments, as described by the following reactions:

and

$$
\mathrm{CO}_{2}+8 \mathrm{H}^{+}+8 \mathrm{e}^{-} \rightarrow \mathrm{CH}_{4}+2 \mathrm{H}_{2} \mathrm{O}
$$

$$
{ }^{*} \mathrm{CH}_{3} \mathrm{COOH} \rightarrow{ }^{*} \mathrm{CH}_{4}+\mathrm{CO}_{2}
$$

where ${ }^{*}$ indicates the intact transfer of the methyl position to $\mathrm{CH}_{4}$. Reactions (2) and (3) describe carbonate-reduction and acetate fermentation pathways, respectively (Whiticar, 1999). The former process is the dominant methanogenic pathway in sulfate-free marine sediments, whereas in freshwater environments the two processes are competitive (Takai, 1970; Belyaev et al., 1975; Winfrey et al., 1977). As shown in the $\delta^{13} \mathrm{C}-\mathrm{CH}_{4}$ vs $\delta \mathrm{D}-\mathrm{CH}_{4}$ diagram (Fig. 6), where the isotopic compositional fields for the two different methanogenic pathways are reported (Whiticar et al., 1986), both carbonate reduction and acetate fermentation likely contribute to $\mathrm{CH}_{4}$ production in lake Paterno. Hydrogen, which in July was detected in dissolved gas samples from depths $\geq 25 \mathrm{~m}$ (Tab. 3), is an important intermediate in mineralization processes of organic matter under anaerobic conditions, e.g. it functions as electron donor by methanogenic and sulfate-reducing

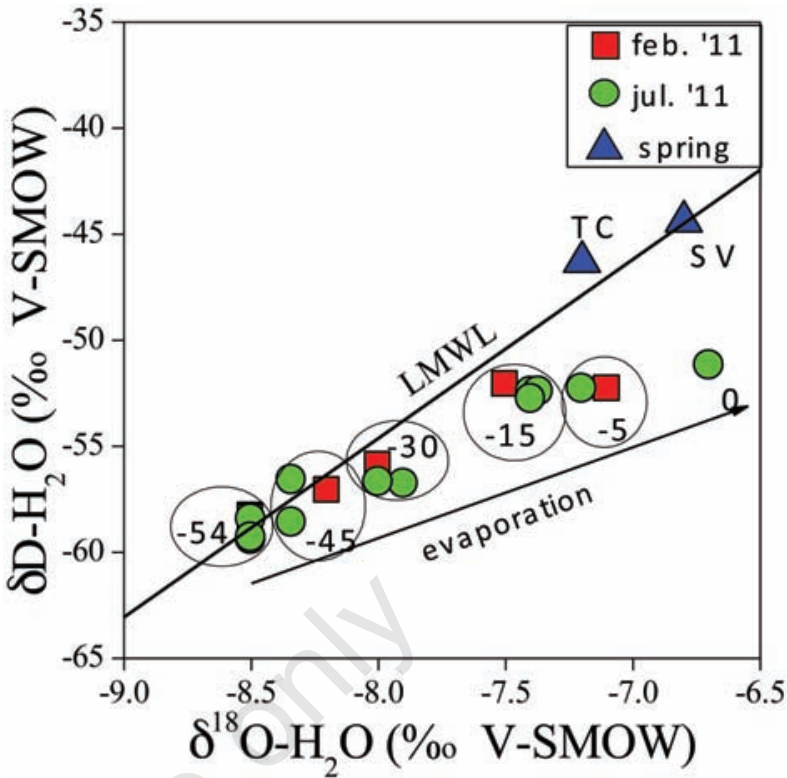

Fig. 5. $\delta \mathrm{D}-\mathrm{H}_{2} \mathrm{O} v s \delta^{18} \mathrm{O}-\mathrm{H}_{2} \mathrm{O}$ plot of lake Paterno water in February and June 2011. Water samples were collected each $5 \mathrm{~m}$ from the surface to the bottom. The local meteoric water line (LMWL) (Giggenbach, 1988) was also reported. Square, February 2011; circle, July 2011; triangle, spring.

Tab. 3. Chemical composition of dissolved gases $\left(\mathrm{CO}_{2}, \mathrm{~N}_{2}, \mathrm{CH}_{4}, \mathrm{Ar}, \mathrm{O}_{2}, \mathrm{Ne}\right.$ and $\left.\mathrm{H}_{2}\right)$ collected in February and July 2011 from the surface to the bottom (each $5 \mathrm{~m}$ ) at lake Paterno. Theoretical $\mathrm{CO}_{2}$ concentrations $\left(\mathrm{CO}_{2 \mathrm{eq}}\right)$ were also reported. Concentrations of dissolved

\begin{tabular}{|c|c|c|c|c|c|c|c|c|c|c|}
\hline Sample depth & Date & $\mathrm{CO}_{2}$ & $\mathrm{~N}_{2}$ & $\mathrm{CH}_{4}$ & Ar & $\mathrm{O}_{2}$ & $\mathrm{Ne}$ & $\mathrm{H}_{2}$ & TOT & $\mathrm{CO}_{2 \mathrm{eq}}$ \\
\hline $0 \mathrm{~m}$ & Feb. 11, 2011 & nd & 769 & nd & 16 & 161 & 0.008 & nd & 946 & 466 \\
\hline $5 \mathrm{~m}$ & Feb. 11, 2011 & nd & 776 & nd & 16 & 148 & 0.008 & nd & 940 & 1270 \\
\hline $10 \mathrm{~m}$ & Feb. 11, 2011 & nd & 774 & nd & 15 & 164 & 0.008 & nd & 953 & 1940 \\
\hline $15 \mathrm{~m}$ & Feb. 11, 2011 & nd & 778 & nd & 16 & 158 & 0.008 & nd & 951 & 1680 \\
\hline $20 \mathrm{~m}$ & Feb. 11, 2011 & nd & 781 & nd & 16 & 148 & 0.008 & nd & 945 & 1460 \\
\hline $25 \mathrm{~m}$ & Feb. 11, 2011 & nd & 771 & nd & 16 & 160 & 0.008 & nd & 948 & 1170 \\
\hline $30 \mathrm{~m}$ & Feb. 11, 2011 & nd & 780 & nd & 16 & 146 & 0.008 & nd & 943 & 1220 \\
\hline $35 \mathrm{~m}$ & Feb. 11, 2011 & nd & 775 & nd & 16 & 144 & 0.008 & nd & 935 & 1240 \\
\hline $40 \mathrm{~m}$ & Feb. 11, 2011 & nd & 769 & nd & 15 & 155 & 0.008 & nd & 939 & 1160 \\
\hline $45 \mathrm{~m}$ & Feb. 11, 2011 & 33 & 769 & 1.5 & 16 & 158 & 0.008 & nd & 977 & 1180 \\
\hline $50 \mathrm{~m}$ & Feb. 11, 2011 & 94 & 774 & 5.0 & 16 & 73 & 0.008 & nd & 961 & 1060 \\
\hline 54 m (bottom) & Feb. 11, 2011 & 155 & 766 & 15 & 16 & 54 & 0.008 & nd & 1106 & 1840 \\
\hline $0 \mathrm{~m}$ & July 23, 2011 & nd & 558 & nd & 13 & 175 & 0.006 & nd & 746 & 95 \\
\hline $5 \mathrm{~m}$ & July 23, 2011 & 3.6 & 677 & nd & 17 & 199 & 0.008 & nd & 896 & 854 \\
\hline $10 \mathrm{~m}$ & July 23, 2011 & 13 & 673 & nd & 17 & 11 & 0.010 & nd & 714 & 1360 \\
\hline $15 \mathrm{~m}$ & July 23, 2011 & 78 & 664 & nd & 16 & nd & 0.008 & nd & 757 & 1500 \\
\hline $20 \mathrm{~m}$ & July 23, 2011 & 191 & 635 & 6.2 & 16 & nd & 0.008 & nd & 847 & 1470 \\
\hline $25 \mathrm{~m}$ & July 23, 2011 & 322 & 644 & 32 & 16 & nd & 0.008 & 25 & 1014 & 1480 \\
\hline $30 \mathrm{~m}$ & July 23, 2011 & 306 & 634 & 94 & 16 & nd & 0.008 & 38 & 1049 & 1430 \\
\hline $35 \mathrm{~m}$ & July 23, 2011 & 325 & 649 & 145 & 16 & nd & 0.008 & 29 & 1135 & 1400 \\
\hline $40 \mathrm{~m}$ & July 23, 2011 & 319 & 662 & 162 & 17 & nd & 0.010 & 140 & 1160 & 1460 \\
\hline $45 \mathrm{~m}$ & July 23, 2011 & 373 & 667 & 329 & 17 & nd & 0.010 & 253 & 1386 & 1420 \\
\hline $50 \mathrm{~m}$ & July 23, 2011 & 385 & 677 & 439 & 17 & nd & 0.010 & 234 & 1518 & 1460 \\
\hline 54 m (bottom) & July 23, 2011 & 426 & 679 & 493 & 17 & nd & 0.010 & 334 & 1615 & 3530 \\
\hline
\end{tabular}
gases are in $\mu \mathrm{mol} / \mathrm{L}$.

nd, not detected. 
bacteria (Mah et al., 1977; Zehnder, 1978; Thauer and Badziong, 1980). As also observed in other meromictic lakes (Schweizer and Aragno, 1975; Conrad et al., 1983; Bianchi et al., 2010), during the stratified period (July), $\mathrm{H}_{2}$ likely diffused from the lake sediment toward the surface and progressively consumed by hydrogen-oxidizing bacteria during its migration (Aragno and Schlegel, 1981; Bowien and Schlegel, 1981).

The carbon isotope signature of dissolved $\mathrm{CO}_{2}\left(\delta^{13} \mathrm{C}\right.$ $\mathrm{CO}_{2}>-11 \%$ V-PDB) is heavier than that produced by a biogenic source $\left(\delta^{13} \mathrm{C}-\mathrm{CO}_{2} \leq-20 \%\right.$ V-PDB) (O'Leary, 1988; Hoefs, 2008), but lighter than the bubbling $\mathrm{CO}_{2}$ of the SV spring $\left(\delta^{13} \mathrm{C}_{-} \mathrm{CO}_{2} \leq-3.08 \%\right.$ V-PDB $)$. This implies, at least, two possible sources for the dissolved $\mathrm{CO}_{2}$ of lake Paterno: i) bacterial-driven reactions, such as denitrification, methanogenesis, and $\mathrm{Fe}^{3+}, \mathrm{Mn}^{3+}$ and $\mathrm{SO}_{4}{ }^{2-}$ reduction (Wetzel, 2001; Schlesinger, 2005), occurring within the lake; ii) deep fluid circulation system related to the Tuscan Roman Degassing Structure (TRDS; Chiodini et al., 2004), characterized by $\mathrm{CO}_{2}$ produced by a combination of different processes, such as i) mantle degassing and ii) thermo-metamorphic reactions within the Mesozoic limestone and/or the metamorphic basement (e.g. Minissale, 2004; Chiodini et al., 2011). The possible occurrence of $\mathrm{CO}_{2}$ addition from a sublacustrine source supports the idea that ground collapses, related to deep piping processes caused by underground circulation of highly mineralized $\mathrm{CO}_{2}\left(\mathrm{H}_{2} \mathrm{~S}\right)$-rich fluids, is the main genetic mechanism for the sinkholes of the S. Vittorino plain, as also suggested by Caramanna et al. (2008).

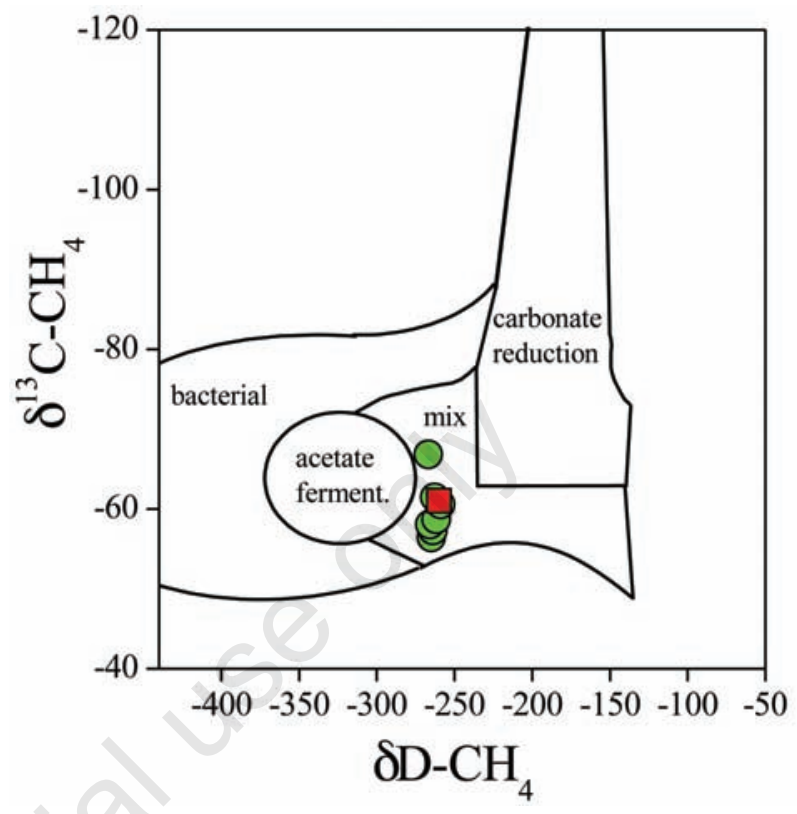

Fig. 6. $\delta^{13} \mathrm{C}_{-} \mathrm{CH}_{4} v s \delta \mathrm{D}-\mathrm{CH}_{4}$ plot of lake Paterno water in February and June 2011. Isotopic compositional fields for gases produced by carbonate-reduction and acetate fermentation (Schoell 1980; 1988; Whiticar 1999) were also reported. Square, February 2011; circle, July 2011.

Tab. 4. $\delta^{13} \mathrm{C}-\mathrm{CO}_{2}$ (expressed as \%o V-PDB), $\delta^{13} \mathrm{C}-\mathrm{CH}_{4}$ (expressed as \%o V-PDB) and $\delta \mathrm{D}-\mathrm{CH}_{4}$ (expressed as \%o V-SMOW) ratios of gas samples collected from lake Paterno at selected depths in February and July 2011.

\begin{tabular}{|c|c|c|c|c|c|}
\hline Sample depth & Date & $\delta^{13} \mathrm{C}-\mathrm{CO}_{2 \mathrm{STRIP}}$ & $\delta^{13} \mathrm{C}-\mathrm{CO}_{2}$ & $\delta^{13} \mathrm{C}-\mathrm{CH}_{4}$ & $\delta \mathrm{D}-\mathrm{CH}_{4}$ \\
\hline $50 \mathrm{~m}$ & Feb. 11, 2011 & na & & -58.1 & na \\
\hline $54 \mathrm{~m}$ (bottom) & Feb. 11, 2011 & -9.71 & -10.92 & -60.9 & -259 \\
\hline San Vittorino & Feb. 11, 2011 & -3.08 & & na & na \\
\hline Sample depth & Date & $\delta^{13} \mathrm{C}-\mathrm{CO}_{2 \text { STRIP }}$ & $\delta^{13} \mathrm{C}-\mathrm{CO}_{2}$ & $\delta^{13} \mathrm{C}-\mathrm{CH}_{4}$ & $\delta \mathrm{D}-\mathrm{CH}_{4}$ \\
\hline $5 \mathrm{~m}$ & July 23,2011 & -8.89 & -10.10 & na & na \\
\hline $10 \mathrm{~m}$ & July 23, 2011 & -9.04 & -10.25 & na & na \\
\hline $15 \mathrm{~m}$ & July 23, 2011 & -9.02 & -10.23 & na & na \\
\hline $20 \mathrm{~m}$ & July 23, 2011 & -9.16 & -10.37 & -56.1 & na \\
\hline $25 \mathrm{~m}$ & July 23, 2011 & -9.31 & -10.52 & -56.3 & -264 \\
\hline $30 \mathrm{~m}$ & July 23, 2011 & -9.15 & -10.36 & -57.1 & -263 \\
\hline $35 \mathrm{~m}$ & July 23, 2011 & -9.02 & -10.23 & -57.9 & -265 \\
\hline $40 \mathrm{~m}$ & July 23, 2011 & -8.94 & -10.15 & -58.5 & -261 \\
\hline $45 \mathrm{~m}$ & July 23, 2011 & -8.82 & -10.03 & -60.4 & -258 \\
\hline $50 \mathrm{~m}$ & July 23, 2011 & -8.76 & -9.97 & -61.3 & -262 \\
\hline $54 \mathrm{~m}$ (bottom) & July 23, 2011 & -8.61 & -9.82 & -66.7 & -266 \\
\hline
\end{tabular}

na, not analyzed. 
The $\delta^{13} \mathrm{C}_{\text {DIC }}$ values, which are produced by combining the $\delta^{13} \mathrm{C}$ values of the main inorganic carbon species $\left(\mathrm{HCO}_{3}{ }^{-}\right.$and $\left.\mathrm{CO}_{2}\right)$, are in the same range of the $\delta^{13} \mathrm{C}^{-} \mathrm{CO}_{2}$ ones (Tab. 1). Isotopic fractionation caused by reaction between dissolved $\mathrm{CO}_{2}$ and $\mathrm{HCO}_{3}{ }^{-}$is quantified by the enrichment factor $\left(\varepsilon_{2}\right)$, as follows (Mook et al., 1974):

$\varepsilon_{2}=\delta^{13} \mathrm{C}-\mathrm{HCO}_{3}{ }^{-}-\delta^{13} \mathrm{C}^{-\mathrm{CO}_{2}}=9483 / \mathrm{T}(\mathrm{K})-23.9$

Theoretical $\delta^{13} \mathrm{C}_{\text {DIC }}$ values $\left(\delta^{13} \mathrm{C}_{\text {DIC calc }}\right)$ can be computed by:

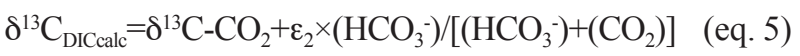

The $\delta^{13} \mathrm{C}_{\text {DICcalc }}$ range from -1.1 and $-0.3 \%$ V-PDB, i.e. they are significantly less negative than the measured $\delta^{13} \mathrm{C}_{\text {DIC }}$ values (Tab. 1). The large difference between measured and calculated $\delta^{13} \mathrm{C}_{\mathrm{DIC}}$ values suggests that $\mathrm{CO}_{2}$ produced by both biogenic processes and added to the lake from the deep abiogenic sources has not achieved an isotopic equilibrium with $\mathrm{HCO}_{3}$.

Moreover, theoretical $\mathrm{CO}_{2}$ concentrations $\left(\mathrm{CO}_{2 \mathrm{eq}}\right)$ calculated on the basis of water chemistry are significantly higher than those measured (Tab. 3), indicating that both $\mathrm{HCO}_{3}{ }^{-}$concentrations and $\mathrm{pH}$ values are not (or not only) controlled by this gas. It is worthy of noting that the $\delta^{13} \mathrm{C}_{\text {DIC calc }}$ values are similar to those measured in water samples from springs of the San Vittorino plain, which range from -0.1 to $1.7 \%$ V-PDB (Petitta et al., 2011).

\section{Processes controlling chemical and isotope compositions of water and dissolved gases along the vertical profiles}

The temperature vertical profiles (Fig. 3a) indicated that during the summer period (July) a well-defined thermal stratification established at lake Paterno, whereas in winter (February) the lake water was (almost) completely homogenized. The occurrence of annual meromixis is called monomixis, a typical feature of non-freezing lakes in temperate climates (Boehrer and Schultze, 2008). Seasonal meromixis at lake Paterno is likely created and sustained by both i) biogenic processes, i.e. decomposition of organic material and dissolution of its end products (Walker and Likens, 1975), and ii) lake morphology (Lemmin, 1995). In February, relatively high concentrations of $\mathrm{HCO}_{3}^{-}, \mathrm{Ca}^{2+}, \mathrm{NH}_{4}^{+}, \mathrm{Si}, \mathrm{Fe}, \mathrm{Mn}, \mathrm{P}, \mathrm{Ba}, \mathrm{CO}_{2}$ and $\mathrm{CH}_{4}$ (Tabs. 1, 2 and 3) were only measured in the bottom waters, suggesting that such enrichment processes, mainly occurring within the bottom sediments, cannot completely be masked by water circulation in the mixolimnion. In July, the stable hypolimnion allows a pronounced increase of the non-atmospheric dissolved gases starting from depth $>5-8 \mathrm{~m}$ (Tab. 3 ), whereas the vertical profiles of solute major solutes and trace species (Tabs. 1 and 2) are similar to those measured in February. During this period, the thin epilimnion of lake Paterno is episodically re-circulated due to wind and/or diurnal-nocturnal temperature fluctuations, causing the release of $\mathrm{CO}_{2}$ and $\mathrm{CH}_{4}$ migrated up to the thermocline from the anoxic deep waters. Such a frequent degassing process, coupled with photosynthesis, contributed to the abrupt decrease of the non-atmospheric dissolved gases approaching the lake surface (Tab. 3). The relatively low $\mathrm{Ca}^{2+}$ and $\mathrm{HCO}_{3}{ }^{-}$concentrations measured in the shallow water layer (0-5 m depth) in July is likely related to calcite precipitation caused by the relatively high temperature up to $23.2^{\circ} \mathrm{C}$ at the lake surface. To validate this hypothesis, we calculated the Saturation Index (SI) with respect to the main salts (calcite, dolomite, fluoride and halite) of water samples from lake Paterno with the PHREEQC-2 computer program using the WATEQ4F thermodynamic database (Parkhurst and Appelo, 1999). Our results (Tab. 5) show that the two $\mathrm{Ca}^{2+}$-bearing carbonate minerals (calcite and dolomite) are slightly oversaturated, thus mineral precipitation efficiently controls the distribution of $\mathrm{Ca}^{2+}$ and $\mathrm{HCO}_{3}{ }^{-}$along the lake vertical profile.

The $\mathrm{CO}_{2}$ vertical profile in the hypolimnion developed in July (Fig. 7) highlighted the occurrence of two different layers: in the shallower one (layer I; depth $<25 \mathrm{~m}$ ), $\mathrm{CO}_{2}$ had a strong decrease toward the surface; in the deeper one (layer II; depth $>25 \mathrm{~m}$ ), the $\mathrm{CO}_{2}$ concentrations diminished at relatively low rate as depth was decreasing. The separation between layers I and II was also marked by the inversion in the behavior of the $\delta^{13} \mathrm{C}_{-} \mathrm{CO}_{2}$ values. The carbon isotopic ratio indeed decreased from the lake bottom to the depth of $25 \mathrm{~m}$, whereas it increased from 25 to $5 \mathrm{~m}$. This suggests that photosynthesis plays an important role also in layer $\mathrm{I}$, leading to a significant $\mathrm{CO}_{2}$ consumption and, consequently, to a ${ }^{13} \mathrm{C}$-enrichment of the residual $\mathrm{CO}_{2}$. In layer II, where the presence of abundant suspended matter (Palozzi et al., 2010) prevents the solar radiation to infiltrate, the vertical patterns of $\mathrm{CO}_{2}$ concentration and $\delta^{13} \mathrm{C}_{-}-\mathrm{CO}_{2}$ are controlled by both contribution of isotopically heavy abiogenic $\mathrm{CO}_{2}$ from the bottom and biogenic $\mathrm{CO}_{2}$ production. The progressive decrease of $\mathrm{CH}_{4}$ concentrations and the simultaneous increase of the $\delta^{13} \mathrm{C}_{-} \mathrm{CH}_{4}$ values at decreasing depth (Fig. 8) is likely due to anaerobic oxidation, which seems to be more efficient at depths $>40 \mathrm{~m}$, probably because at shallower depth the relatively low $\mathrm{CH}_{4}$ concentrations are not attractive to methanotrophs (Whiticar, 1999). Nitrate and sulfate can function as electron acceptors for microbial oxidation of organic material. Therefore, denitrification favors the decrease of $\mathrm{NO}_{3}{ }^{-}$in the deepest portion of layer II (Fig. 4b), where significant sulfate reduction also occurred (Tab. 1). Ammonia increase with depth may partly be dependent on $\mathrm{NO}_{3}{ }^{-}$reduction (Buresh and Patrick, 1981). However, in eutrophic lakes the activity of this lat- 
ter process is an order of magnitude lower than denitrification (Stewart et al., 1982). This suggests that $\mathrm{NH}_{4}{ }^{+}$was mainly generated primarily in the lake sediments by the deamination of proteins and amino acids (Molongoski and Klug, 1980), as also supported by the dramatic $\mathrm{NH}_{4}{ }^{+}$increase at the lake bottom (Fig. 4c).

The concentration patterns of $\mathrm{Fe}$ and Mn drastically increased toward the maximum depth. This may reflect a sediment source for both $\mathrm{Fe}^{2+}$ and $\mathrm{Mn}^{2+}$ (Davison et al., 1980), which are relatively high in waters at the measured $\mathrm{pH}$ values. Furthermore, Fe and $\mathrm{Mn}$ reduction, as well as $\mathrm{CO}_{2}$ dissolution, contributed to lower the $\mathrm{pH}$ values. Oxidation processes, with formation of insoluble $\mathrm{Fe}$ - and Mn-hydroxides, is the main factor limiting the concentrations of these two elements in the lake. The redox cycles of $\mathrm{Fe}$ and $\mathrm{Mn}$ control the distribution and speciation of other elements, such as phosphorus (Mortimer, 1942; Balistrieri et al., 1992; Hongve, 1997). Phosphorus accumulation in anoxic deep lake waters is related to its rapid endogenous cycle (Schwedt, 1996): phosphate is assimilated during the photosynthesis of living organism and is released again within a few days; phosphorus is then scavenged from the epilimnion due to sorption to $\mathrm{Fe}$ and $\mathrm{Mn}$ precipitates and eventually, it is released by microbial degradation of detritus during sedimentation and during sediment diagenesis (Gächter and Bloesch, 1985; Gächter and Mares, 1985; Veronesi et al., 2002). Therefore, during the summer period the vertical distribution of $\mathrm{P}$, as well as that of $\mathrm{Fe}$ and $\mathrm{Mn}$, was regulated by: i) limited upward diffusion of these elements from the bottom sediments up to the of $\sim 45-50 \mathrm{~m}$; and ii) co-precipitation of insoluble $\mathrm{Fe}-\mathrm{Mn}$ - and P-bearing compound at relatively shallow depth, where oxygen from different sources was available. In winter, the lake had a unique aerobic mixolimnion, thus significant concentrations of these three elements only occurred in lake water just above the bottom sediments.

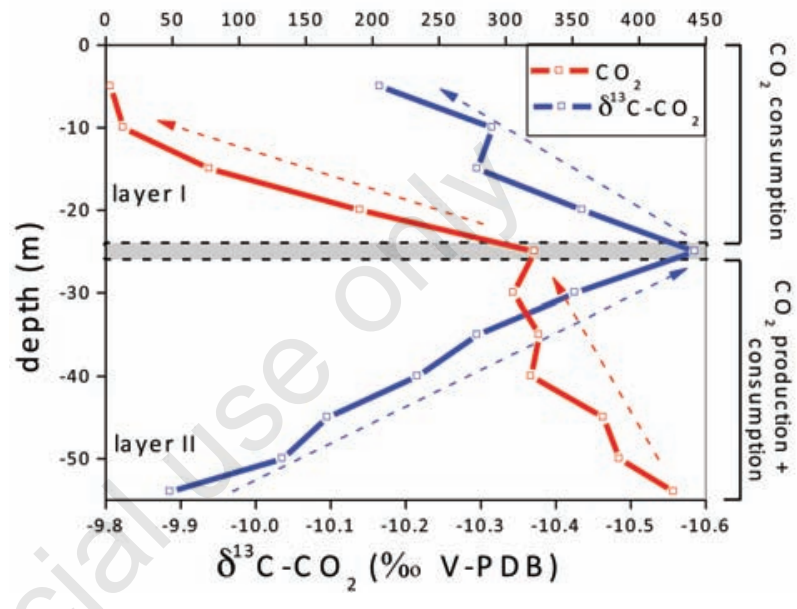

Fig. 7. Vertical profile of $\mathrm{CO}_{2}$ concentrations (in $\mu \mathrm{mol} \mathrm{L}^{-1}$ ) and $\delta^{13} \mathrm{C}^{-} \mathrm{CO}_{2}$ values (in \%o V-PDB) of lake Paterno in June 2011, from the depth of $5 \mathrm{~m}$ to the lake bottom.

Tab. 5. Saturation index with respect to calcite, dolomite, fluoride and halite of water samples collected from lake Paterno.

\begin{tabular}{|c|c|c|c|c|c|}
\hline Sample depth & Date & Calcite & Dolomite & Fluoride & Halite \\
\hline$\overline{0 \mathrm{~m}}$ & Feb. 11, 2011 & 0.86 & 1.01 & -1.97 & -9.09 \\
\hline $5 \mathrm{~m}$ & Feb. 11, 2011 & 0.42 & 0.14 & -2.01 & -9.06 \\
\hline $10 \mathrm{~m}$ & Feb. 11, 2011 & 0.23 & -0.24 & -1.63 & -9.02 \\
\hline $15 \mathrm{~m}$ & Feb. 11, 2011 & 0.29 & -0.11 & -1.97 & -9.07 \\
\hline $20 \mathrm{~m}$ & Feb. 11, 2011 & 0.37 & 0.05 & -1.88 & -9.08 \\
\hline $25 \mathrm{~m}$ & Feb. 11, 2011 & 0.46 & 0.21 & -1.69 & -9.06 \\
\hline $30 \mathrm{~m}$ & Feb. 11, 2011 & 0.44 & 0.18 & -1.41 & -9.06 \\
\hline $35 \mathrm{~m}$ & Feb. 11, 2011 & 0.48 & 0.31 & -1.25 & -9.03 \\
\hline $40 \mathrm{~m}$ & Feb. 11, 2011 & 0.49 & 0.30 & -1.84 & -9.10 \\
\hline $45 \mathrm{~m}$ & Feb. 11, 2011 & 0.48 & 0.26 & -1.43 & -9.02 \\
\hline $50 \mathrm{~m}$ & Feb. 11, 2011 & 0.53 & 0.36 & -1.18 & -9.05 \\
\hline 54 m (bottom) & Feb. 11, 2011 & 0.37 & 0.02 & -1.77 & -9.08 \\
\hline $0 \mathrm{~m}$ & July 23, 2011 & 1.06 & 1.92 & -2.45 & -8.98 \\
\hline $5 \mathrm{~m}$ & July 23, 2011 & 0.56 & 0.63 & -2.12 & -8.91 \\
\hline $10 \mathrm{~m}$ & July 23, 2011 & 0.51 & 0.36 & -1.86 & -8.95 \\
\hline $15 \mathrm{~m}$ & July 23, 2011 & 0.45 & 0.20 & -1.83 & -8.97 \\
\hline $20 \mathrm{~m}$ & July 23, 2011 & 0.46 & 0.23 & -1.51 & -8.89 \\
\hline $25 \mathrm{~m}$ & July 23, 2011 & 0.46 & 0.23 & -1.87 & -9.00 \\
\hline $30 \mathrm{~m}$ & July 23, 2011 & 0.46 & 0.24 & -1.87 & -8.98 \\
\hline $35 \mathrm{~m}$ & July 23, 2011 & 0.47 & 0.25 & -1.60 & -8.96 \\
\hline $40 \mathrm{~m}$ & July 23, 2011 & 0.45 & 0.21 & -1.91 & -8.99 \\
\hline $45 \mathrm{~m}$ & July 23, 2011 & 0.48 & 0.25 & -1.82 & -8.99 \\
\hline $50 \mathrm{~m}$ & July 23, 2011 & 0.50 & 0.29 & -1.41 & -8.89 \\
\hline $54 \mathrm{~m}$ (bottom) & July 23, 2011 & 0.21 & -0.29 & -1.29 & -8.89 \\
\hline
\end{tabular}


Whatever the thickness of the water layer, we may refer the lake bottom as the layer III of Lake Paterno.

\section{CONCLUSIONS}

Bacteria-driven processes occurring in the hypolimnion of lake Paterno during summer, when thermal stratification favored by climate conditions produced the isolation of deep waters from the lake surface, are the main responsible for the distribution of biogenic $\left(\mathrm{CO}_{2}\right.$, $\mathrm{CH}_{4}, \mathrm{H}_{2}, \mathrm{NH}_{4}^{+}$and $\left.\mathrm{P}\right)$ and minerogenic $\left(\mathrm{Fe}^{2+}, \mathrm{Mn}^{2+}, \mathrm{Si}\right.$ and $\mathrm{Ba}$ ) products along the vertical lake profile. Based on the chemical and isotopic characteristics of water and dissolved gases, different layers are distinguished: i) layer I, i.e. the epilimnion (from the surface to $-8 \mathrm{~m}$ depth), where photosynthesis and frequent water mixing occur preventing accumulation of both biogenic elements and dissolved gases, and the relatively high temperature causes significant calcite precipitation; ii) layer II, the anoxic hypolimnion (depth $>10 \mathrm{~m}$ ), whose chemistry is controlled by the activity of different bacteria populations; iii) layer III, the lake bottom (-54 m depth), where the highest concentrations are recorded for those elements likely released at the sediment-water interface (Fig. 9a). During winter, the decrease of lake temperature, likely coupled with the effect of winter winds, allows the mixing of layers I and II, whereas continuous biogenic and minerogenic production maintains significant ion and dissolved gas enrichments in a thin water layer at the contact with the bottom sediments (Fig. 9b). The seasonal stratification of lake Paterno sheds light on the behavior of living macro-organisms, which during summer are forced to populate only the epilimnion. Occasional lake water mixing, caused for example by anomalous weather conditions, during the stratified period cannot be excluded. However, the low temperature of the deep waters $\left(\sim 7^{\circ} \mathrm{C}\right)$ suggests that such events can be forecasted to be rare, and lake Paterno can be considered monomictic. The carbon isotopic signature of $\mathrm{CO}_{2}$ indicates that this gas partly originated from the hydrothermal system feeding the mineralized springs of the San Vittorino valley. This external input of $\mathrm{CO}_{2}$ may play a significant role for the development of the seasonal stratification of lake Paterno. Moreover, the presence of deep-originated $\mathrm{CO}_{2}$ within the lake supports the hypothesis that lake Paterno is a deep piping sinkhole (DPS), i.e. it originated from ground collapses caused by deep piping processes triggered by uprising acidic fluids from depth.

However, to exhaustively define the mechanisms regulating the temporal evolution of the water and dissolved gas chemistry of this lake, a comprehensive investigation of the distribution of bacteria and archaebacteria populations along the vertical water column is strongly recommended.

\section{ACKNOWLEDGEMENTS}

This work was supported by the Laboratory of Fluid and Rock Geochemistry (Department of Earth Sciences of Florence) and by the Ciudad de la Energia (Spain) and CNRIGG (Florence) in the framework of the project Chemical composition of free- and diffuse-gases in $\mathrm{CO}_{2}$-rich natural analogues. Two anonymous reviewers are thanked for their help to improve an early version of the manuscript.

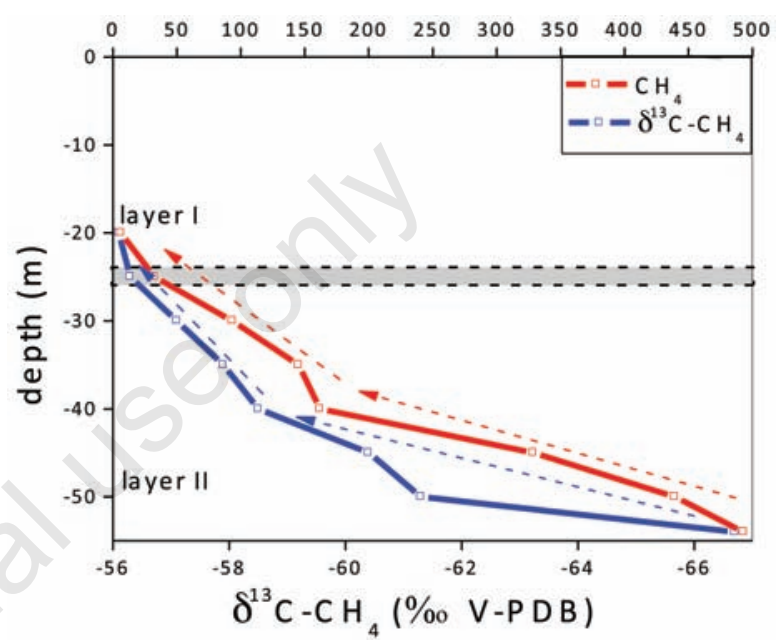

Fig. 8. Vertical profile of $\mathrm{CH}_{4}$ concentrations (in $\mu \mathrm{mol} \mathrm{L}^{-1}$ ) and $\delta^{13} \mathrm{C}^{-} \mathrm{CH}_{4}$ values (in \%o V-PDB) of lake Paterno in June 2011, from the depth of $20 \mathrm{~m}$ to the lake bottom.
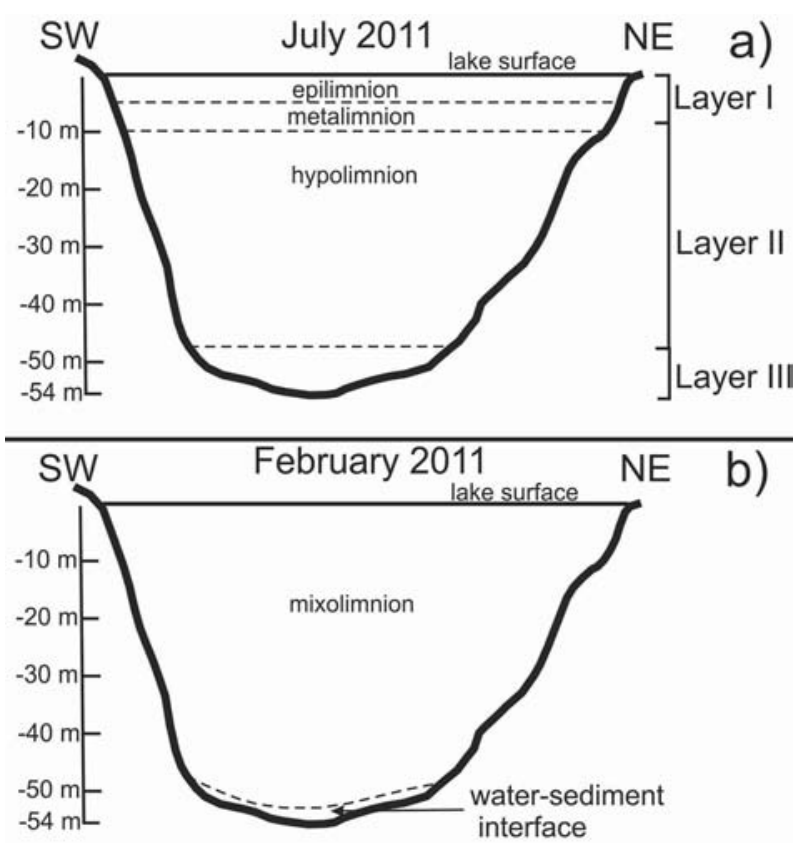

Fig. 9. Schematic section of lake Paterno along the vertical profile in a) July 2011 and b) February 2011. 


\section{REFERENCES}

Aliotta A, Chiarelli B, Panzanaro M, Muti P, 1982. Il Lago di Paterno. Comune Castel S. Angelo.

Annunziatellis A, Beaubien SE, Ciotoli G, Lombardi S, Nisio S, Nolasco F, 2004. Studio dei parametri geologici e geochimici per la comprensione dei meccanismi genetici degli sprofondamenti nella piana di S. Vittorino, p. 63-82. In: Proc. Symp. State of the art on the Study of Sinkholes, and the Role of National and Local Authorities in the Management of the Territory, Roma, Italy, 20-21 May 2004.

Aragno M, Schlegel HG, 1981. The hydrogen-oxidizing bacteria. In: M.P. Starr, H. Stolp, H.G. Trüper, A. Ballows and H.G. Schlegel (eds.), The prokaryotes. A handbook of habitats, isolation and identification of bacteria. Springer-Verlag, Berlin.

Balistrieri LS, Murray JW, Paul B, 1992. The cycling of iron and manganese in the water column of Lake Sammamish, Washington. Limnol. Oceanogr. 37:510-528.

Barker JF, Fritz P, 1981. Carbon isotope fractionation during microbial methane oxidation. Nature 293:289-291.

Belyaev SS, Finkelstein ZI, Ivanov MV, 1975. Intensity of bacterial methane formation in ooze deposits of certain lakes. Microbiology 44:272-275.

Bersani P, Castellano F, 2002. I sinkhole della Piana di S. Vittorino (Rieti) e il rischio idraulico connesso, p. 47-61. In: Proc. Symp. Le voragini catastrofiche, un nuovo problema per la Toscana, Grosseto, Italy, March 2000.

Bianchi L, Mannelli F, Viti C, Adessi A, De Philippis R, 2010. Hydrogen-producing purple non-sulfur bacteria isolated from the trophic lake Averno. Int. J. Hydr. En. 35:1221312223.

Boehrer B, Schultze M, 2008. Stratification of lakes. Rev. Geophys. 46:RG2005.

Bowien B, Schlegel HG, 1981. Phyiology and biochemistry of aerobic hydrogen-oxidizing bacteria. Annu. Rev. Microbiol. 35:405-452.

Brancaccio L, D’Argenio B, Ferreoli V, Stanzione D, Taddeucci A, Voltaggio M, 1988. I travertini di Rocchetta a Volturno (Molise): datazioni con 230Th e modello de posizionale. Mem. Soc. Geol. It. 41:673-683.

Buresh RJ, Patrick WH, 1981. Nitrate reduction to ammonium and organic nitrogen in an estuarine sediment. Soil Biol. Biochem. 13:279-283.

Caliro S, Chiodini G, Izzo G, Minopoli C, Signorini A, Avino R, Granieri D, 2008. Geochemical and biochemical evidence of lake overturn and fish kill at lake Averno, Italy. J. Volcanol. Geoth. Res. 178:305-316.

Capelli G, Petitta M, Salvati R, 2000. Relationships between catastrophic subsidence hazards and groundwater in the Velino Valley (Central Italy), p. 123-136. In: Proc. Symp. Land Subsidence SISOLS. Ravenna, Italy, April 2000.

Caramanna G, Ciotoli G, Nisio S, 2008. A review of natural sinkhole phenomena in Italian plain areas. Natural Hazards 45:145-172.

Catenacci V, 1992. Censimento dei dissesti causati dal crollo di cavità sotterranee verificatesi in Italia dal dopoguerra al 1990. Mem. Serv. Geol. Naz. XLVII.

Carpenter SR, 1983. Lake geometry: Implications for production and sediment accretion rates. J. Theor. Biol. 105:273-286.

Centamore E, Fumanti F, Nisio S, 2002. The central-northern
Apennines geological evolution from Triassic to Neogene time. Boll. Soc. Geol. It., Spec. 2002/1:181-197.

Centamore E, Nisio S, 2003. The effects of uplift and tilting in the Central Apennine. Quaternary Int. 101-102:93-101.

Centamore E, Nisio S, Rossi D, 2004. Aspetti geologico-strutturali in relazione alla formazione della 'sinkhole plain' di S. Vittorino, p. 285-298. In: Proc. Symp. State of the art on the Study of sinkholes, and Role of National and Local Authorities in the Management of the Territory. Roma, Italy, 20-21 May 2004.

Centamore E, Nisio S, Rossi D, 2009. The San Vittorino Sinkhole Plain: relationship between bedrock structure, sinking processes, seismic events and hydrothermal springs. Ital. J. Geosci. 128:629-639.

Chiodini G, 1996. Gases dissolved in groundwaters: analyticalmethods and examples of applications in central Italy, p. 135-148. In: L. Marini \& G. Ottonello (eds.), Proc. Symp. Environmental Geochemistry. Castelnuovo di Porto, Roma, Italy, 22-26 May 1996.

Chiodini G, Cardellini C, Amato A, Boschi E, Caliro S, Frondini F, Ventura G, 2004. Carbon dioxide Earth degassing and seismogenesis in central and southern Italy. Geophys. Res. Lett. 31:L07615.

Chiodini G, Caliro S, Cardellini C, Frondini F, Inguaggiato S, Matteucci F, 2011. Geochemical evidence for and characterization of $\mathrm{CO}_{2}$ rich gas sources in the epicentral area of the Abruzzo 2009 earthquakes. Earth Planet. Sci. Lett. 304:389-398.

Ciotoli G, Di Filippo M, Nisio S, Romagnoli C, 1998. La piana di S. Vittorino: dati preliminari sugli studi geologici, strutturali, geomorfologici, geofisici e geochimici, p. 200-201. In: Proc. Symp. Giovani Ricercatori di Geologia Applicata. Chieti, Italy, 22-24 October 1998.

Ciotoli G, Di Filippo M, Nisio S, Romagnoli C, 2001. La piana di S. Vittorino: dati preliminari sugli studi geologici, strutturali, geomorfologici, geofisici e geochimici. Mem. Soc. Geol. It. 56:297-308.

Coleman ML, Shepherd TJ, Rouse JE, Moore GR, 1982. Reduction of water with zinc for hydrogen isotope analysis. Anal. Chem. 54:993-995.

Conrad R, Aragno M, Seiler W, 1983. Production and consumption of hydrogen in a eutrophic lake. Appl. Environ. Microbiol. 45:502-510.

Crema C. 1924. Sprofondamenti carsici del gennaio e febbraio 1915 nella valle del Velino (Aquila). Extract: Tra i monti del Lazio e dell'Abruzzo, Roma.

Davison W, Heaney SI, Talling JF, Rigg E, 1980. Seasonal transformations and movements of iron in a productive English lake with deep water anoxia. Schweiz. Z. Hydrol. 42:196224.

Epstein S, Mayeda TK, 1953. Variation of the ${ }^{18} \mathrm{O} /{ }^{16} \mathrm{O}$ ratio in natural waters. Geochim. Cosmochim. Acta 4:213-224.

Evans WC, White LD, Rapp JB, 1998. Geochemistry of some gases in hydrothermal fluids from the southern San Juan de Fuca ridge. J. Geophys. Res. 15:305-313.

Faccenna C, Florindo F, Funicello R, Lombardi S, 1993. Tectonic setting and Sinkhole Features: case histories from western Central Italy. Quaternary Proceedings 3:47-56.

Fairbridge RW, 1968. The Encyclopedia of Geomorphology. Reinhold (ed.), New York: 1295 pp. 
Gächter R, Mares A, 1985. Does settling seston release soluble reactive phosphorus in the hypolimnion of lakes? Limnol. Oceanogr. 30:364-371.

Gächter R, Bloesch J, 1985. Seasonal and vertical variation in the $\mathrm{C}: \mathrm{P}$ ratio of suspended and settling seston of lakes. Hydrobiologia 128:193-200.

Giggenbach WF, 1988. Isotopic and chemical assessment of geothermal potential of the Colli Albani area, Latium region, Italy. Appl. Geochem. 3:475-486.

Gutiérrez F., Guerrero J, Lucha P, 2008. A genetic classification of sinkholes illustrated from evaporite paleokarst exposure in Spain. Environ. Geol. 53:993-1006.

Hoefs J, 2008. Stable isotope chemistry. Springer, Berlin: 260 pp.

Hongve D, 1997. Cycling of iron, manganese, and phosphate in a meromictic lake. Limnol. Oceanogr. 42:635-647.

Hutchinson GE, 1957. A treatise on limnology. 1. Geography, Physics and Chemistry. J. Wiley, New York: 1015 pp.

Kling GW, Clark MA, Compton HR, Devine JD, Evans WC, Humphrey AM, Koenigsberg EJ, Lockwood JP, Tuttle ML, Wagner GN, 1987. The 1986 Lake Nyos gas disaster in Cameroon, West Africa. Science 236:169-175.

Kusakabe M, Tanyileke GZ, McCord SA, Schladow SG, 2000. Recent $\mathrm{pH}$ and $\mathrm{CO}_{2}$ profiles at Lake Nyos and Monoun, Cameroon: implications for the degassing strategy and its numerical simulation. J. Volcanol. Geotherm. Res. 97:241260.

Lehman JT, 1975. Reconstructing the rate of accumulation of lake sediment. The effect of sediment focusing. Quatern. Res. 5:541-550.

Lemmin U, 1995. Limnologie physique, p. 61-106. In: R. Pourriot and M. Meybeck (eds.), Limnologie Générale. Masson, Paris, France.

Mah RA, Ward DM, Baresi L, Glass TL, 1977. Biogenesis of methane. Annu. Rev. Microbiol. 31:309-341.

Marinelli R, 1995. Le terre contese. Comune di Borgovelino (Ri), Gruppo Tipografico Editoriale (ed.), L'Aquila, Italy.

Matsubaya O, Sakai $\mathrm{H}, 1978$. D/H and ${ }^{18} \mathrm{O} /{ }^{16} \mathrm{O}$ fractionation factors in evaporation of water at 60 and $80^{\circ} \mathrm{C}$. Geochem. J. 12:121-126.

Michetti AM, Brunamonte F, Serva L, Whitney RA, 1994. Seismic hazard assessment from paleosismological evidence in the Rieti region, Central Italy. Bull. I.A.E.G., Spec. Vol.:6382.

Minissale A, 2004. Origin, transport and discharge of $\mathrm{CO}_{2}$ in Central Italy. Earth-Sci. Rev. 66:89-141.

Minissale A, Kerrick DM, Magro M.T. Murrel MT, Paladini M, Rihs S, Sturchio NC, Tassi F, Vaselli O, 2002. Structural, hydrological, geochemical and climatic parameter affecting the precipitation of Quaternary travertines in the region north of Rome (Italy). Earth Planet. Sci. Lett. 203:709-728.

Molongoski JJ, Klug MJ, 1980. Anaerobic metabolism of particulate organic matter in the sediments of particulate organic matter in the sediments of a hypereutrophic. Freshwater Biol. 10:507-518.

Mook WG, Bommerson JC, Staverman WH, 1974. Carbon isotope fractionation between dissolved bicarbonate and gaseous carbon dioxide. Earth Planet. Sci. Lett. 22:169-176.

Mortimer CH, 1942. The exchange of dissolved substances between mud and water in lakes: III and IV. J. Ecol. 30:147-201.
Neuendorf K, Mehl J, Jackson J, 2005. Glossary of geology. 5th ed., Alexandria, VA, American Geological Institute: 779 pp.

Nisio S, 2003. I fenomeni di sprofondamento: stato delle conoscenze ed alcuni esempi in Italia centrale. Ital. J. Quat. Sci. 16:121-132

Nisio S, 2008. I fenomeni naturali di sinkhole nelle aree di pianura italiane. Mem. Descr. Carta Geol. It. 85:475.

Nisio S, Caramanna G, Ciotoli G, 2005. Sinkholes hazard in Italy: first results on the inventory and analysis of some case studies, p. 03922. In: Proc. Symp. European Geosciences Union (EGU), Geoph. Res. Proc., Vienna, 24-29 April 2005.

Nisio S, Caramanna G, Ciotoli G, 2007. Sinkholes hazard in Italy: first results on the inventory and analysis of some case studies, p. 23-45. In: M. Parise and J. Gunn (eds.), Natural and anthropogenic hazards in karst: Recognition, Analysis and Mitigation. Geol. Soc. London Spec. Pub. 279.

O'Leary MH, 1988. Carbon isotopes in photosynthesis. BioScience 38:328-336.

Palozzi R, Congestri R, Quartararo M, Marcelli M, Sprovieri M, Rumolo P, Kirin T, Laiou A, Tomasino MP, Schirone B, 2010. The underwater ecological survey of a historic sinkhole in the Central Italy by means of stable isotope analysis and scientific diving techniques, p. 57. In: Proc. Symp. Second International Workshop on Research in Shallow Marine and Fresh Water Systems, Milazzo, 3-10 October 2010, Miscellanea INGV, 7.

Parkhurst DL, Appelo CAJ, 1999. User's guide to PHREEQC (version 2), a computer program for speciation, batch-reaction, one dimensional transport, and inverse geochemical calculations. U.S. Geological Survey Water-Resources, Investigations Report 99-4259: 312 pp.

Persichetti N, 1893. Viaggio archeologico sulla via salaria nel circondario di Cittaducale: $173 \mathrm{pp}$.

Persichetti N, 1910. La Via Salaria nei circondarii di Roma e Rieti. Tip. della R. Accademia dei Lincei, Roma: 157 pp.

Petitta M, Primavera P, Tuccimei P, Aravena R, 2011. Interaction between deep and shallow groundwater systems in areas affected by Quaternary tectonics (Central Italy): a geochemical and isotope approach. Environ. Earth Sci. 63:11-30.

Riccardi M, 1951. Nuove ricerche sulla Piana di S. Vittorino. Boll. Soc. Geogr. It. IV(V):7-11.

Rowe Jr GL, 1994. Oxygen, hydrogen and sulfur isotope systematics of the crater lake system of Poas volcano, Costa Rica. Geochem. J. 28:263-287.

Salata GG, Roelke LA, Cifuentes LA, 2000. A rapid and precise method for measuring stable carbon isotope ratios of dissolved inorganic carbon. Mar. Chem. 69:153-161.

Salvati R, Sasowsky ID, 2002. Development of cover collapse sinkholes in areas of groundwater discharge. J. Hydrol. 264:1-11.

Schlesinger WH, 2005. Treatise on Geochemistry. vol. 8, Biogeochemistry, Elsevier, Oxford, UK.

Schoell M, 1980. The hydrogen and carbon isotopic composition of methane from natural gases of various origins. Geochim. Cosmochim. Acta 44:649-661.

Schoell M, 1988. Multiple origins of methane in the Earth. Chem. Geol. 71:1-10.

Schwedt S, 1996. Taschenatlas der Umweltchemie. Thieme Verlag: 248 pp.

Schweizer C, Aragno M, 1975. Étude des hydrogénobactéries 
dans un petit lac (Le Loclat ou Lac de Saint-Blaise). Bull. Soc. Neuchatel. Sci. Nat. 98:79-87.

Stewart WDP, Preston T, Peterson HG, Christofi N, 1982. Nitrogen cycling in eutrophic freshwaters. Philosoph. Transact. Royal Soc. B 296:491-509.

Takai Y, 1970. The mechanism of methane fermentation in flooded paddy soil. Soil Sci. Plant Nutr. 16:238-244.

Tassi F, Montegrossi G, Vaselli O, 2004. Metodologie di campionamento ed analisi di fasi gassose. Int. Rep. CNR-IGG, Florence, n. 1/2003: 16 pp.

Tassi F, Vaselli O, Luchetti G, Montegrossi G, Minissale A, 2008. Metodo per la determinazione dei gas disciolti in acque naturali. Int. Rep. CNR-IGG, Florence, n. 10450: 11 pp.

Tassi F, Vaselli O, Tedesco D, Montegrossi G, Darrah T, Cuoco E, Mapendano MY, Poreda R, Delgado Huertas A, 2009. Water and gas chemistry at Lake Kivu (DRC): geochemical evidence of vertical and horizontal heterogeneities in a multi-basin structure. Geochem. Geophys. Geosyst. 10:Q02005.

Thauer RK, Badziong W, 1980. respiration with sulfate as electron acceptor. In: C.J. Knowles (ed.), Diversity of bacterial respiratory systems. CRC Press, Boca Raton, 2:65-85.

Vaselli O, Tassi F, Montegrossi G, Capaccioni B, Giannini L, 2006. Sampling and analysis of fumarolic gases. Acta Vulcanol. 1-2:65-76.

Veronesi M, Barbieri A, Hanselmann KW, 2002. Phosphorus, carbon and nitrose enrichment during sedimentaqtion in a seasonally anoxic lake (Lake Lugano, Switzerland). J. Limnol. 61:215-223.
Walker KF, Likens GE, 1975. Meromixis and a reconsidered typology of lake circulation patterns. Verh. Int. Ver. Theor. Angew. Limnol. 19:442-458.

Waltham T, Bell F, Culshaw M, 2005. Sinkholes and subsidence. Springer Verlag, Berlin Heidelberg, New York: 382 pp.

Wetzel RG, 2001. Limnology: Lake and River Ecosystems. 3rd Ed., Academic, San Diego, Calif., USA.

Whitfield M, 1978. Activity coefficients in natural waters, p. 153-300. In: R.M. Pytkowicz (ed.), Activity Coefficients in Electrolyte Solutions. CRC Press, Boca Raton.

Whiticar MJ, 1999. Carbon and hydrogen isotope systematics of bacterial formation and oxidation of methane. Chem. Geol. 161:291-314.

Whiticar MJ, Faber E, Schoell M, 1986. Biogenic methane formation in marine and freshwater environments: $\mathrm{CO}_{2}$ reduction vs acetate fermentation - isotope evidence. Geochim. Cosmochim. Acta 50:693-709.

Williams P, 2003. Dolines, p. 304-310. In: J. Gunn (ed.), Encyclopedia of caves and karst science. Taylor and Francis Group, New York.

Winfrey MR, Nelson DR, Klevickis SC, Zeikus JG, 1977. Association of hydrogen metabolism with methanogenesis in Lake Mendota sediments. Appl. Environ. Microbiol. 33:312318.

Zehnder AJB, 1978. Ecology of methane formation, In: R. Michell (ed.), Water pollution microbiology. J. Wiley \& Sons, Inc., New York.

Zhang J, Quay PD, Wilbur DO, 1995. Carbon isotope fractionation during gas-water exchange and dissolution of $\mathrm{CO}_{2}$. Geochim. Cosmochim. Acta 59:107-114. 